Agronomy, Soils, \& Environmental Quality

\title{
Efficient land water management practice and cropping system for increasing water and crop productivity in semi-arid tropics
}

\author{
Prasad Jairam Kamdi $^{1} \quad$ Dillip Kumar Swain ${ }^{2}$ (1) $\quad$ Suhas P Wani ${ }^{1}$ \\ ${ }^{1}$ ICRISAT Development Center, Research program-Asia, International Crops Research Institute for the Semi-Arid Tropics, Patancheru, Telangana, 502 324, \\ India \\ ${ }^{2}$ Agricultural and Food Engineering Department, Indian Institute of Technology Kharagpur, Kharagpur, West Bengal, 721 302, India
}

\section{Correspondence}

Agricultural and Food Engineering Department, Indian Institute of Technology Kharagpur, Kharagpur 721 302, West Bengal, India

Email:swain@agfe.iitkgp.ac.in

\begin{abstract}
In Indian semi-arid tropics (SATs), low water and crop productivity in Vertisols and associated soils are mainly due to poor land management and erratic and low rainfall occurrence. This study was conducted from 2014 to 2016 at the ICRISAT in India to test the effect of broad bed furrows (BBF) as land water management against conventional flatbed planting for improving soil water content (SWC) and water and crop productivity of three cropping systems: sorghum [Sorghum bicolor (L.) Moench]-chickpea (Cicer arientinum L.) and maize (Zea mays)-groundnut (Arachis hypogaea L.) as sequential and pearl millet [Pennisetum glaucum (L.)] + pigeonpea [Cajanus cajan (L.) Millsp.] as intercropping, grown under different nutrients management involving macronutrients $(\mathrm{N}, \mathrm{P}$, and $\mathrm{K})$ only and combined application of macro- and micronutrients. The results stated that the SWC in BBF was higher over flatbed by $9.35-10.44 \%$ in $0-$ to $0.3-\mathrm{m}, 4.56-9.30 \%$ in $0.3-$ to $0.6-\mathrm{m}$ and $3.85-5.26 \%$ in $0.6-$ to $1.05-\mathrm{m}$ soil depths during the cropping season. Moreover, depletion of the soil water through plant uptake was higher in BBF than in flatbed. Among the cropping systems, sorghum-chickpea was the best in bringing highest system equivalent yield and water productivity with the combined application of macro- and micronutrients. The BBF minimized water stress at critical crop growth stages leading to increase crop yield and water productivity in SATs. Thus, BBF along with the application of macro- and micronutrients could be an adaptation strategy to mitigate erratic rainfall due to climate change in SATs.
\end{abstract}

\footnotetext{
Abbreviations: BBF, broad-bed furrows; $\mathrm{C} 1$, sorghum-chickpea sequential cropping treatment; $\mathrm{C} 2$, maize-groundnut sequential cropping treatment; $\mathrm{C} 3$, pearl millet + pigeonpea intercropping treatment; CF, chemical fertilizer; DAS, days after sowing; L1, flatbed treatment; L2, broad bed furrow treatment; LWM, land-water management; N1, control (no fertilizer); N2, 100\% recommended application of N, P, and K as chemical fertilizer; N3, N2 + 100\% recommended application of S, Zn, and B as chemical fertilizer; N4, 50\% N2 + 50\% N as vermicompost; OC, organic carbon; SATs, semi-arid tropics; SEY, system equivalent yield; SWC, Soil Water Content; WP, Water Productivity.
} 


\section{1 | INTRODUCTION}

Water scarcity and increasing land degradation due to climate change are the most critical challenges today in rain-fed agriculture which covers $80 \%$ of the world agriculture (FAO, 2005; Wani et al., 2008). The effects of climate change on agriculture is seen in increasing water demand, reducing water availability, and decreasing water productivity (WP). It is assessed that one-third of the world's population will face physical water scarcity by 2025 (Viala, 2007). The Food and Agriculture Organization (FAO) of the United Nation's study on water scarcity projected a general reduction in rainfall, an increase in extreme events of rainfall in semi-arid areas, and an increase in temperature. These extreme events of weather have a direct effect on the water availability, which accounts for about $70 \%$ of global water withdrawals in agriculture (The World Bank, 2020) and has a negative effect on crop production systems.

Crop failure in the regions of semi-arid tropics (SATs) is due to climatic variability like uncertainty in rainfall (Parry et al., 2007), water scarcity (Ringler, Zhu, Cai, Koo, \& Wang, 2010), rising atmospheric temperature (Boomiraj, Wani, Garg, Aggarwal, \& Palanisami, 2010), increase in frequency and duration of droughts (Alexandratos \& Bruinsma, 2012), and an increase in dryness and wetness (Kesava et al., 2013).

In addition to climate parameters, successful crop production systems depend on land-water-nutrients management and efficient cropping system with high WP. Vertisols are the major soils in SATs, which occupy $267 \mathrm{~m} \mathrm{ha}^{-1}$ across all continents (Dudal \& Eswaran, 1988) and constitute approximately $22 \%$ of the total geographical area of India (Murthy, 1988). In Indian SAT, Vertisols are cultivated post-rainy season on stored moisture and kept mostly fallow during the rainy season due to waterlogging and sticky nature when wet and hardness with cracks when dry, both of which reduce workability (Greene-Kelly. R., 1974; Michaels, 1982; Sreedevi, Wani, Rao, Singh, \& Ahmed, 2009; Wani et al., 2002; Wani et al., 2016). The crop failure in the drylands is due to poor land-water management practices in Vertisols which lead to inefficient utilization of rainwater and less conservation of soil moisture. These land and water related issues in Vertisols have been addressed through many studies on soil and moisture conservation measures such as broad bed furrows (BBF), conservation furrows, ridge and furrow, compartmental bunding, tied ridge and furrow, and contour cultivation. Studies on these land-water management (LWM) practices increased yield of sorghum [Sorghum bicolor (L.) Moench] by $13.16 \%$ in BBF (Patil, Muzumdar, \& Pore, 1991), groundnut (Arachis hypogaea L.) by $12.8 \%$ in graded bund (Barai, Patil, \& Patil, 1991) and pearl millet [Pennisetum glaucum (L.)] by $17 \%$ in ridge and furrow (Singh, \& Verma,

\section{Core Ideas}

- Broad bed furrow (BBF) was an efficient land water management practice in SATs.

- BBF conserved more soil water than flatbed in the dry period of the cropping.

- Higher systems and water productivity were recorded in sequential than intercropping.

- Land-water-crop system management is an adaptation strategy to erratic rainfall.

1996) over flatbed planting. Studies were also conducted on LWM practices to reduce runoff and increase soil moisture using $\mathrm{BBF}$ and ridge and furrow along with drought-tolerant crops. These studies indicated higher moisture conservation and crop productivity (Ramesh \& Devasenapathy, 2007; Thakur, Kushwaha, \& Sinha, 2011; Venkateswarlu et al., 2008), reduced seasonal runoff, improved soil water content (SWC), and reduced annual soil loss (Pathak, Wani, \& Sudi, 2011) in BBF compared to the flatbed.

In dryland agriculture, water is an important natural resource and primary limiting factor (Falkenmark \& Rockström, 2008) for crop production, which is classified as green and blue water resources. Green water is the major part of the rainfall which is held in soil and available to plants and is returned back to the atmosphere through evapotranspiration. Alternatively, blue water is the part of precipitation that enters into streams and lakes and recharges groundwater reserves (Falkenmark, 1995). It is important to note that high WP in dryland agriculture could be achieved by integrating land-water-crop-nutrient management which includes appropriate utilization of green water through LWM practices, and robust cropping systems, which includes resilient crops like sorghum, pearl millet, maize, pigeonpea [Cajanus cajan (L.) Millsp.], chickpea (Cicer arientinum $\mathrm{L}$.), and groundnut in sequential and inter cropping.

Poor land management along with degraded soil further worsens the situation in rain-fed agriculture, and several researchers (Rego, Rao, Seeling, Pardhasaradhi, \& Rao, 2003; Rego, Wani, Sahrawat, \& Pardhasaradhi, 2007; Sahrawat, Wani, Rego, Pardhasaradhi, \& Murthy, 2007; Twomlow, Love, \& Walker, 2008; Zougmore, Zida, \& Kambou, 2003) revealed that soil infertility is a threat for crop production. Wani, Chander, Sahrawat, and Pardhasaradhi (2015) reported that deficiency of secondary, micro- (mainly sulfur, S; boron, $\mathrm{B}$; and zinc, $\mathrm{Zn}$ ), and macronutrients are mainly responsible for the degradation of soil fertility in SAT. In SATs, nutrient deficiency is one of the major constraints to crop 


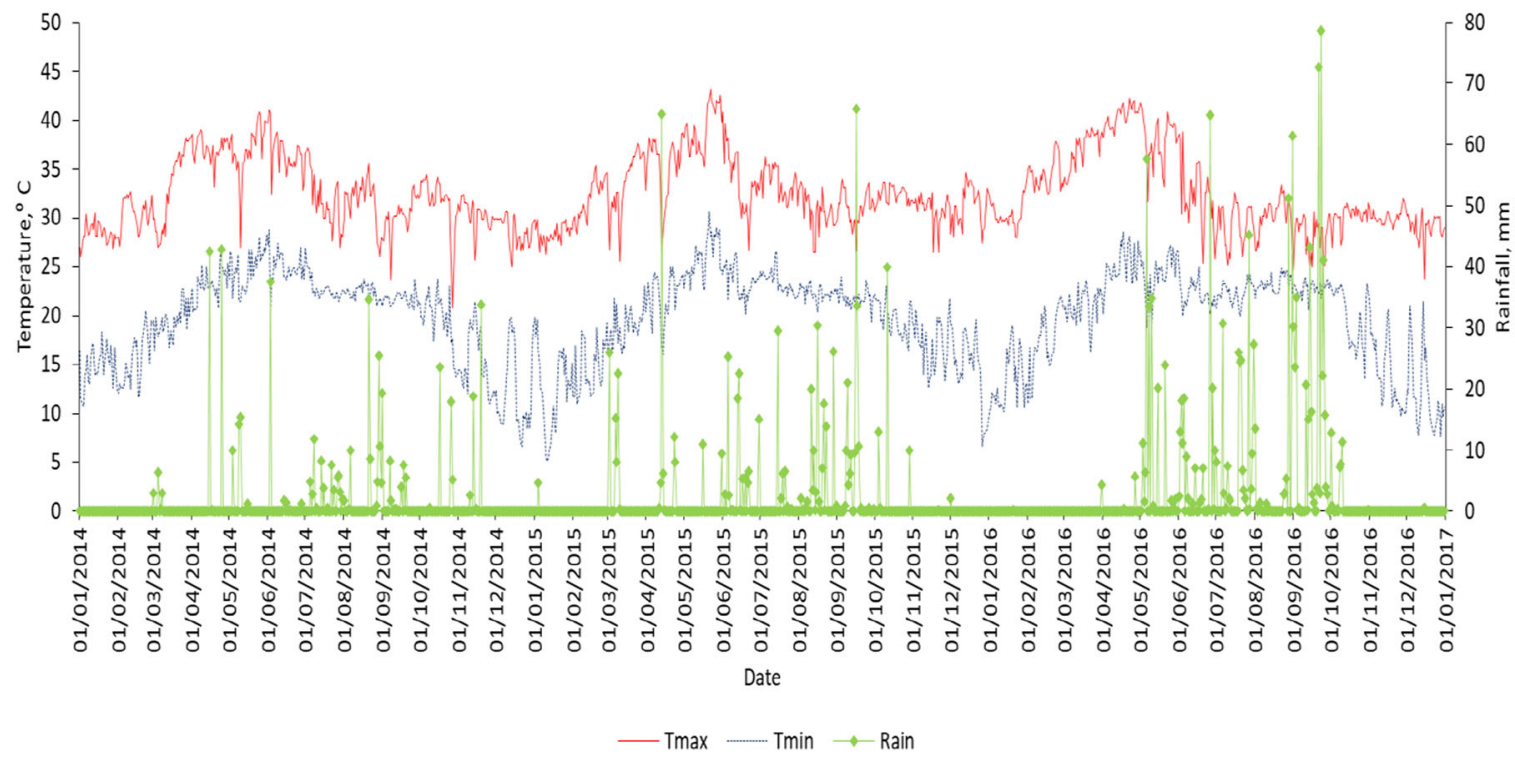

F I G U R E 1 Daily rainfall (mm), maximum (Tmax), and minimum (Tmin) temperature from 2014 to 2017 at the experimental site. Dates are presented as day/month/year

production systems. Rain-fed soils are often multi-nutrient deficient and need proper nutrient management strategies to bridge the existing gap between attainable yields and farmers' current yield (Sahrawat, Wani, Parthasaradhi, \& Murthy, 2010). In the SATs, the applications of major nutrients like nitrogen $(\mathrm{N})$, phosphorus $(\mathrm{P})$, and potassium $(\mathrm{K})$ are currently practiced (El-Swaify, Pathak, Rego, \& Singh, 1985; Rego et al., 2003; Sharma, Grace, \& Srinivas, 2009). However, very little attention has been paid to diagnose and take corrective measures for secondary- and micronutrient deficiencies in various crop production systems (Rego, Wani, Sahrawat, \& Pardhasaradhi, 2005; Sahrawat et al., 2007, 2011).

The available literature on management of Vertisols through various LWM practices, correcting multi-nutrient deficiencies, and increasing WP in drylands were mainly focused on productivity enhancement in single cropping system. There is a lack in addressing concerns of in-situ green water conservation and systems productivity in multiple cropping, using organic and inorganic nutrient sources for supply of macro- and micronutrients. Based on the previous studies, it was hypothesized that BBF can be an efficient LWM practice for Vertisols, is expected to improve SWC and WP of cropping systems in SATs and can be an adaptation strategy to varying rainfall due to climate change. Therefore, the present study was carried out to compare the BBF as LWM practices with farmer's practice of flatbed planting in three major cropping systems (two sequential cropping: sorghum-chickpea and maizegroundnut; and one intercropping: pearl millet + pigeonpea) for improving SWC, WP, and system equivalent yield (SEY) in SATs.

\section{2 | MATERIALS AND METHODS}

\section{1 | Description of experimental site and soil characteristics}

Field experiments were conducted over two years (20142015 and 2015-2016) at the International Crops Research Institute for the Semi-Arid Tropics (ICRISAT), Patancheru $\left(17.51^{\circ} \mathrm{N}, 78.26^{\circ} \mathrm{E}\right)$, India. The local climate of the study area is semi-arid with an average annual rainfall of $898 \mathrm{~mm}$. The maximum temperature may reach up to $43{ }^{\circ} \mathrm{C}$ in May and minimum may drop to $5{ }^{\circ} \mathrm{C}$ in December (Patil, Wani, \& Garg, 2016). For the experimental period, daily rainfall and maximum and minimum temperature data were collected from Agrometeorology observatory situated at ICRISAT near the experimental site. The rainfall and temperature during the experimental period are shown in Figure 1.

The maximum temperature reached up to 41 and $43.2{ }^{\circ} \mathrm{C}$ whereas the minimum temperature was $6.7^{\circ} \mathrm{C}$ and $5.2{ }^{\circ} \mathrm{C}$ during 2014 and 2015, respectively.

The soil at the experimental site is Vertisol. In order to study the important physical properties of the soil, a profile pit up to $1.05-\mathrm{m}$ depth was dug in different points and initial samples were collected at an increment of 0.1-m depth up to $0.9-\mathrm{m}$, except the last layer of $0.15 \mathrm{~m}$, that is, $0.9-$ to $1.05-\mathrm{m}$. Physical properties like soil texture (sand, silt, and clay content) were analyzed using hydrometer (Klute, 1986), bulk density was analyzed with core sampler (Black, 1965), and water content at field capacity and wilting point were analyzed using pressure plate apparatus (Thorne \& Peterson, 1954). Values of initial physical properties were averaged for 0 - to 0.3-, 0.3- to 0.6-, and 0.6- to 1.05-m depth for respective 
TA B L E 1 Initial physical properties of the top (0- to 0.3-m), middle (0.3- to $0.6-\mathrm{m})$, and bottom (0.6- to $1.05-\mathrm{m})$ soil layers at the experimental site

\begin{tabular}{|c|c|c|c|}
\hline Physical properties & Top & Middle & Bottom \\
\hline Sand, \% & 26.95 & 23.02 & 20.74 \\
\hline Silt, $\%$ & 19.24 & 21.18 & 20.52 \\
\hline Clay, \% & 53.97 & 55.87 & 58.66 \\
\hline Mean bulk density, $\mathrm{g} \mathrm{cm}^{-3}$ & 1.23 & 1.31 & 1.40 \\
\hline Water content at field capacity, $\mathrm{cm} \mathrm{cm}^{-1}$ & 0.38 & 0.42 & 0.46 \\
\hline Water content at wilting point, $\mathrm{cm} \mathrm{cm}^{-1}$ & 0.24 & 0.26 & 0.29 \\
\hline Total available water, $\mathrm{cm} \mathrm{cm}^{-1}$ & 0.14 & 0.16 & 0.17 \\
\hline
\end{tabular}

points and presented in Table 1. Hereafter, 0- to $0.3-\mathrm{m}$ soil depth is denoted as the top layer, 0.3- to 0.6-m depth as the middle layer, and 0.6- to $1.05-\mathrm{m}$ depth as the bottom layer.

For chemical analysis, soil samples were collected from top layer and $\mathrm{pH}$ analysis was done with a glass electrode using a soil/water ratio of 1:2, and organic carbon (OC) was analyzed following the Walkley-Black method (Nelson \& Sommers, 1996). Available P, K, S, B, and Zn were extracted using sodium bicarbonate for P (Olsen \& Sommers, 1982), ammonium acetate for K (Helmke \& Sparks, 1996), $1.5 \mathrm{~g}$ $\mathrm{kg}^{-1}$ calcium chloride for S (Tabatabai, 1996), hot water for B (Keren, 1996), and diethylenetriaminepentaacetic acid (DTPA) reagent for Zn (Lindsay \& Norvell, 1978). Available $\mathrm{P}$ was determined using the colorimetric method and $\mathrm{K}$ was determined by Atomic Absorption Spectrophotometer (AAS). Analyses of S, B, and $\mathrm{Zn}$ were done using Inductively Coupled Plasma Atomic Emission Spectroscopy (ICP-AES). Initial chemical analysis of soil sample from top layer showed a $\mathrm{pH}$ of 7.60 , electrical conductivity $=0.18 \mathrm{dS} \mathrm{m}^{-1}, 0.32 \%$ OC, $2.97 \mathrm{mg} \mathrm{kg}^{-1} \mathrm{P}, 183.43 \mathrm{mg} \mathrm{kg}^{-1} \mathrm{~K}, 7.08 \mathrm{mg} \mathrm{kg}^{-1} \mathrm{~S}$, $0.58 \mathrm{mg} \mathrm{kg}^{-1} \mathrm{~B}$, and $0.25 \mathrm{mg} \mathrm{kg}^{-1} \mathrm{Zn}$.

\section{2 | Experimental set-up and management}

The experiment was laid out in a split-split plot design with 24 treatments and three replications. Three cropping systems namely, sorghum-chickpea sequential cropping (C1), maize-groundnut sequential (C2), and pearl millet + pigeonpea intercropping (C3) were in main plot treatment. Two LWM practices, flatbed (L1) and BBF (L2) were in subplot treatments, and four nutrient management: control, no fertilizer (N1); $100 \%$ recommended application of $\mathrm{N}, \mathrm{P}$, and $\mathrm{K}$ through chemical fertilizer (N2); N2 + 100\% recommended application of S, Zn, and B through CF (N3), and 50\% of $\mathrm{N} 2+50 \%$ of $\mathrm{N}$ through organic fertilizer as vermicompost (N4) were taken in sub-subplot. The BBF system, a $105-\mathrm{cm}$ wide bed with $45-\mathrm{cm}$ wide and $15-\mathrm{cm}$ deep furrows on both sides, was made with the help of bullock drawn Tropicultor implement. Furrows in the BBF treatment were kept opened
T A B L E 2 Cropping period, duration (d), and total water inputs (mm) to crops during 2014-2015 and 2015-2016

\begin{tabular}{|llcc|}
\hline Crop & Cropping period & Duration & $\begin{array}{c}\text { Total } \\
\text { water } \\
\text { inputs }\end{array}$ \\
\hline 2014-2015 & & d & mm \\
\hline Sorghum & 8 July-16 Oct. 2014 & 101 & 203 \\
\hline Maize & 8 July-22 Oct. 2014 & 107 & 226 \\
\hline Pearl millet & 8 July-2 Oct. 2014 & 87 & $202^{\mathrm{a}}$ \\
\hline Pigeonpea & 8 July 2014-6 Jan. 2015 & 183 & $168^{\mathrm{b}}$ \\
\hline Chickpea & 30 Oct. 2014-12 Feb. 2015 & 98 & 150 \\
\hline Groundnut & 30 Oct. 2014-12 Mar. 2015 & 134 & 253 \\
\hline 2015-2016 & & & \\
\hline Sorghum & 13 June-18 Sept. 2015 & 98 & 435 \\
\hline Maize & 13 June-25 Sept. 2015 & 105 & 436 \\
\hline Pearl millet & 13 June-5 Sept. 2015 & 85 & $264^{\mathrm{a}}$ \\
\hline Pigeonpea & 13 June-18 Dec. 2015 & 189 & $299^{\mathrm{b}}$ \\
\hline Chickpea & 13 Oct. 2015-5 Feb. 2016 & 116 & 103 \\
\hline Groundnut & 13 Oct. 2015-29 Feb. 2016 & 140 & 133 \\
\hline
\end{tabular}

a Pearl millet + Pigeonpea

${ }^{\mathrm{b}}$ After harvest of Pearl millet.

up to the end of the field and excess water from the furrows was drained out to drainage channels which further diverted the excess water to the farm pond. A row spacing of $45 \mathrm{~cm}$ was maintained in all four rainy season crops (sorghum, maize, pearl millet, and pigeonpea) and $30-\mathrm{cm}$ row spacing was maintained in two post rainy season crops (chickpea and groundnut). The individual plot size was 4.5 by $20 \mathrm{~m}$ with a 1-m border on both sides to curtail water run-on to between adjacent plots. The seeding rates were $7.5 \mathrm{~kg} \mathrm{ha}^{-1}$ for sorghum, $15 \mathrm{~kg} \mathrm{ha}^{-1}$ for maize, $4 \mathrm{~kg} \mathrm{ha}^{-1}$ for pearl millet, $10 \mathrm{~kg} \mathrm{ha}^{-1}$ for pigeonpea, $75 \mathrm{~kg} \mathrm{ha}^{-1}$ for chickpea, and $150 \mathrm{~kg}$ $\mathrm{ha}^{-1}$ for groundnut. Tropicultor implement was used for land preparation, sowing, fertilizer application, and inter-culture operation. Recommended dose $\left(\mathrm{kg} \mathrm{ha}^{-1}\right)$ of macronutrients as N-P-K were 80-40-30, 100-50-40, 60-30-20, 20-50-0, and 20-40-50 for sorghum, maize, pearl millet + pigeonpea, chickpea, and groundnut, respectively. In addition to these macronutrients, $30 \mathrm{~kg} \mathrm{ha}^{-1} \mathrm{~S}, 10 \mathrm{~kg} \mathrm{ha}^{-1} \mathrm{Zn}$, and $0.5 \mathrm{~kg} \mathrm{ha}^{-1}$ $\mathrm{B}$ were recommended for all the crops. In sub-subplot, fertilizers as per treatments were applied before sowing except for $\mathrm{N}$ in cereals, where $50 \%$ of $\mathrm{N}$ was added as basal and the remaining $50 \%$ at $30 \mathrm{~d}$ after sowing (DAS). Necessary plant protection measures were taken to control insect attack and diseases. Cropping period, duration (d), and total water inputs $(\mathrm{mm})$ for each crop are shown in Table 2. Rainy season crops were grown as rain-fed and sprinkler irrigation was used for pigeonpea, chickpea, and groundnut where $30-\mathrm{mm}$ irrigation was provided at each time during post-rainy season in each year. The number of irrigations provided in post-rainy season 
T A B L E 3 Layer-wise initial soil water content $(\mathrm{SWC} ; \mathrm{cm})$ in broad bed furrows $(\mathrm{BBF})$ and flatbed in three cropping systems

\begin{tabular}{llllrrr} 
Layer & Sorghum-chickpea & & Maize-groundnut & & \multicolumn{2}{l}{ Pearl millet + pigeonpea } \\
& BBF & Flatbed & BBF & \multicolumn{1}{l}{ Flatbed } & BBF & Flatbed \\
Top & $10.41( \pm .42)^{\mathrm{a}}$ & $8.99( \pm .43)$ & $10.04( \pm .40)$ & $9.91( \pm .07)$ & $10.14( \pm .07)$ & $9.49( \pm .21)$ \\
\hline Middle & $11.28( \pm .01)$ & $10.24( \pm .25)$ & $11.00( \pm .36)$ & $10.30( \pm .47)$ & $10.99( \pm .14)$ & $10.61( \pm .21)$ \\
Bottom & $17.75( \pm .08)$ & $17.01( \pm .34)$ & $17.45( \pm .36)$ & $16.44( \pm .40)$ & $17.79( \pm .11)$ & $16.91( \pm .44)$ \\
\hline
\end{tabular}

${ }^{a}$ Values in parentheses are Standard Error of the mean (SEM).

were two for pigeonpea, three for chickpea, and four for groundnut. The two irrigations to pigeonpea were provided during the reproductive stage. For chickpea and groundnut, first irrigation was provided after crop emergence for uniform stand establishment and the second and third irrigations were during the reproductive stage. In groundnut, fourth irrigation was provided before harvesting for better uprooting of pods.

\section{3 | Soil moisture monitoring}

Eighteen access tubes were installed up to $1.05-\mathrm{m}$ soil depth in each land management and cropping system treatments for the N management 'N3' only. A calibrated neutron probe (503DR Hydroprobe, CPN International, Concord, CA) was used to monitor SWC (Wani, Singh, \& Pathak, 1999) on selected intervals up to $1.05-\mathrm{m}$ depth. The source of neutron probe was lowered down to $1.05-\mathrm{m}$ soil depth in $0.15-\mathrm{m}$ depth increments and SWC were recorded from seven depths. The SWC values at each $0.15-\mathrm{m}$ soil depth were computed into volumetric water content and averaged for top, middle and bottom soil layer.

For each data point, number of values in the data set was three. Standard deviation $(\sigma)$ and standard error were calculated by the following equations:

$$
\sigma=\sqrt{\frac{\sum(X-\bar{X})^{2}}{n-1}}
$$

where $X$ is Individual observations, $\bar{X}$ is the average, and $\mathrm{n}$ is number of observations.

$$
\text { Standard error }=\frac{\sigma}{\sqrt{n}}
$$

First observation of SWC in BBF and flatbed was recorded on 24 DAS of rainy season crops (2014-2015) and were considered as initial SWC (Table 3).

\subsection{System equivalent yield and water productivity}

To compare the yield $\left(\mathrm{kg} \mathrm{ha}^{-1}\right)$ of three cropping systems, the grain yield of all crops in the cropping system were converted to SEY ( $\mathrm{kg}$ sorghum $\mathrm{ha}^{-1}$ ) on the prevailing market price of the produce. Hereafter, respective crop equivalent yields are denoted as sorghum equivalent yield (SGEY), chickpea equivalent yield (CPEY), maize equivalent yield (MZEY), groundnut equivalent yield (GNEY), pearl millet equivalent yield (PMEY), and pigeonpea equivalent yield (PPEY). The SEY of cropping system was calculated considering market price in Indian Rupee (INR). As market prices of the produce (INR $\mathrm{kg}^{-1}$ ) were not fixed during both the years of study, the SEY was calculated for each year.

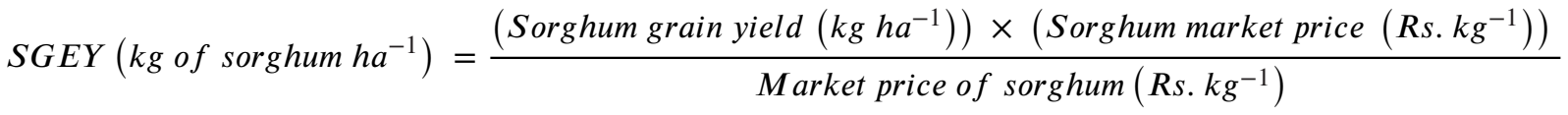

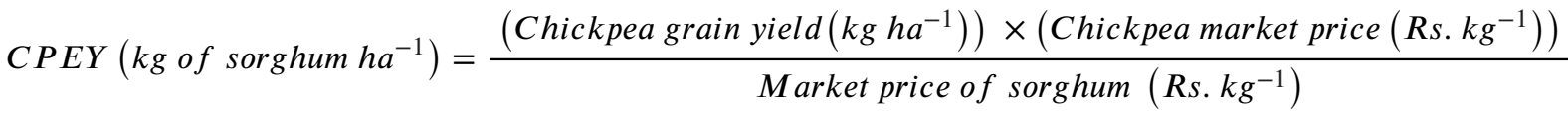

$\operatorname{MZEY}\left(\mathrm{kg}\right.$ of sorghum $\left.\mathrm{ha}^{-1}\right)=\frac{\left(\text { Maize grain yield }\left(\mathrm{kg} \mathrm{ha}^{-1}\right)\right) \times\left(\text { Maize market price }\left(R s . \mathrm{kg}^{-1}\right)\right)}{\text { Market price of sorghum }\left(R s . \mathrm{kg}^{-1}\right)}$ 
GNEY $\left(\mathrm{kg}\right.$ of sorghum $\left.\mathrm{ha}^{-1}\right)=\frac{\left(\text { Groundnut grain yield }\left(\mathrm{kg} \mathrm{ha}^{-1}\right)\right) \times\left(\text { Groundnut market price }\left(R s . \mathrm{kg}^{-1}\right)\right)}{\text { Market price of sorghum }\left(R s . \mathrm{kg}^{-1}\right)}$

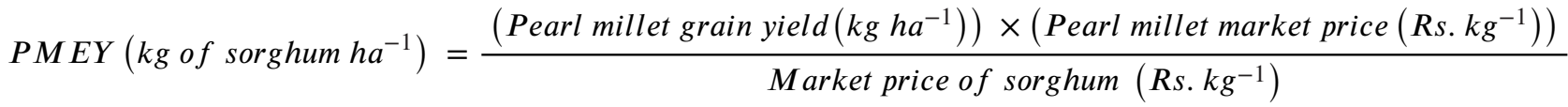

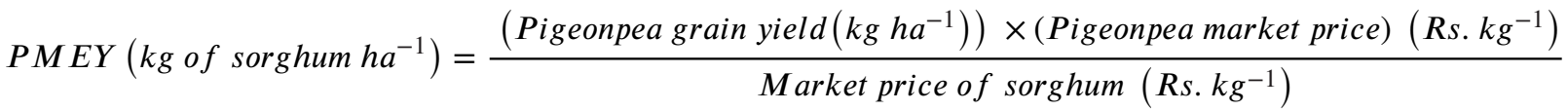

\section{5 | Systems equivalent yield (kg of sorghum per hectare)}

Systems equivalent yield of cropping system was calculated by adding the sorghum equivalent yield of each component crop of cropping system.

$$
\begin{aligned}
& \text { SEY of C1 }=\text { SGEY + CPEY } \\
& \text { SEY of C2 }=\text { MZEY + GNEY } \\
& \text { SEY of C3 = PMEY + PPEY }
\end{aligned}
$$

\section{6 | Water productivity $\left(\mathrm{kg} \mathrm{m}^{-3}\right)$}

In the present study, WP was determined to evaluate the productivity of total water inputs in different management treatments. WP of cropping systems was calculated by the following equation:

$$
\mathrm{WP}=\frac{\mathrm{SEY}}{\mathrm{TWIs}}
$$

Where WP is water productivity of cropping system $(\mathrm{kg}$ $\mathrm{m}^{-3}$ ), SEY is the system equivalent yield of cropping system $\left(\mathrm{kg} \mathrm{ha}^{-1}\right)$, and TWIs is total water inputs $\left(\mathrm{m}^{3} \mathrm{ha}^{-1}\right)$ which includes rainfall + irrigation in a hectare crop area.

\subsection{Statistical analysis}

The data collected were statistically analyzed with analysis of variance test and the least significant difference (LSD) of treatment means at the 5\% level using the $14^{\text {th }}$ edition GenStat (Ireland, 2010). The LSD values were calculated whenever the $F$-test was found to be significant. In the case of nonsignificant effects, the standard error of means (SEM) alone is presented in tables.

\section{3 | RESULTS AND DISCUSSION}

\section{1 | Effect of land-water management practices on soil water content}

Previous studies on LWM were conducted for one or two seasons in either of rainy or post-rainy season crop, where SWC was recorded in top layer for a short period in sole cropping. The present study analyzes SWC in different layers (top, middle, and bottom) for different cropping systems in a dryland ecosystem and is a new approach for understanding the effect of LWM on sustaining crop productivity in SATs.

In two years of the study period (2014-2015 and 20152016), the SWC in BBF among three cropping systems (two sequential: sorghum-chickpea and maize-groundnut, one intercropping: pearl millet + pigeonpea) varied in the range $7.82-16.25 \mathrm{~cm}$ in the top layer, $8.97-15.86 \mathrm{~cm}$ in the middle layer, and $15.82-23.47 \mathrm{~cm}$ in the bottom layer. As compared to BBF, the SWC for corresponding layers in flatbed were lower, 7.15-14.71, 8.58-14.51, and 15.23$22.30 \mathrm{~cm}$ in the top, middle, and bottom layers respectively. These results showed that the SWC in BBF was higher over flatbed by $9.35-10.44 \%$ in the top layer, $4.56-9.30 \%$ in the middle layer, and $3.85-5.26 \%$ in the bottom layer during the cropping period.

The BBF attributed to the formation of raised beds which restricted the velocity of rainwater as runoff and allowed for a longer water retention time in furrows than the flatbed. Moreover, the increased surface area due to raised beds increased horizontal movement of water from furrow to the inner layer of BBF. In addition, raised beds decreased runoff in BBF which allowed more time for water to infiltrate into deeper layers, thereby resulted in increased infiltration rate and water content in the soil profile. However, higher infiltration of rainwater could be due to the typical characteristics of 
Among three cropping systems
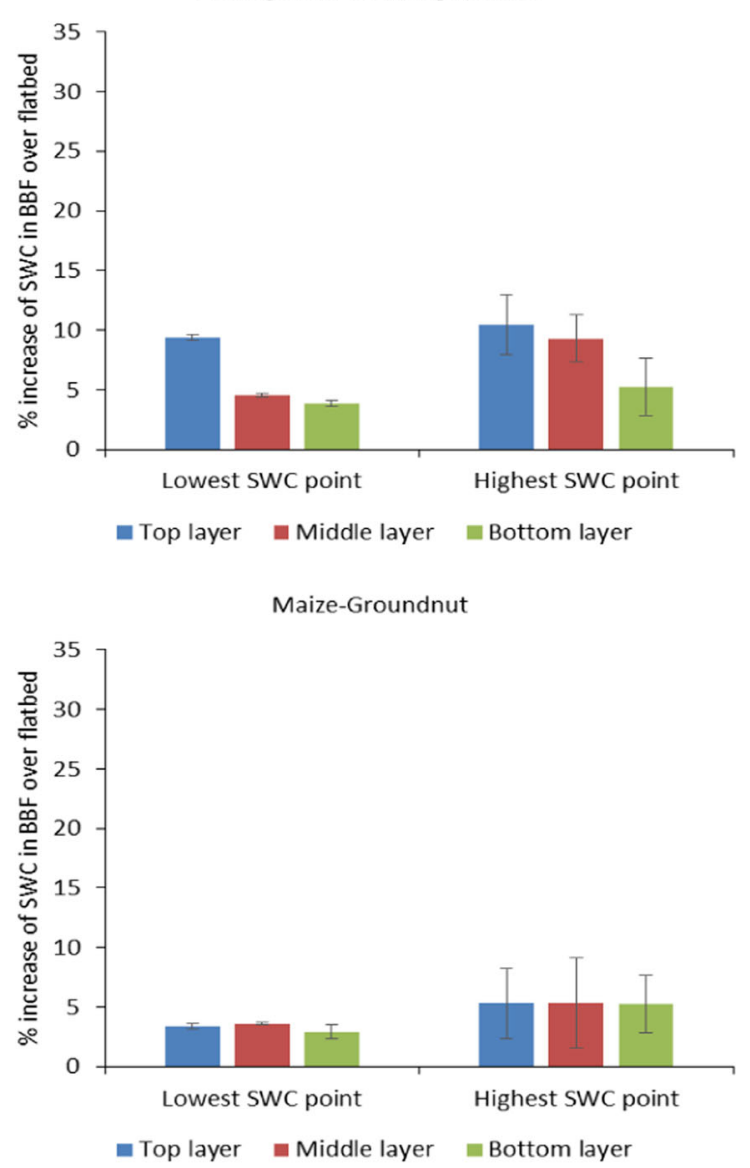

Sorghum-Chickpea

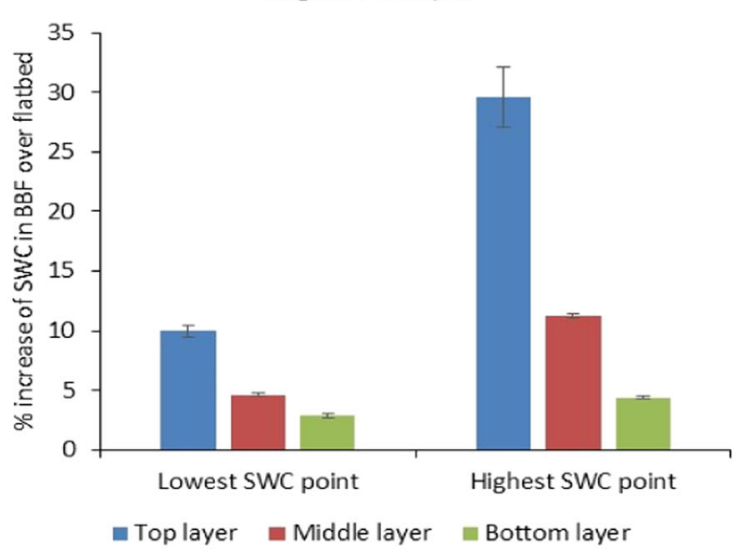

Pearl millet + Pigeonpea

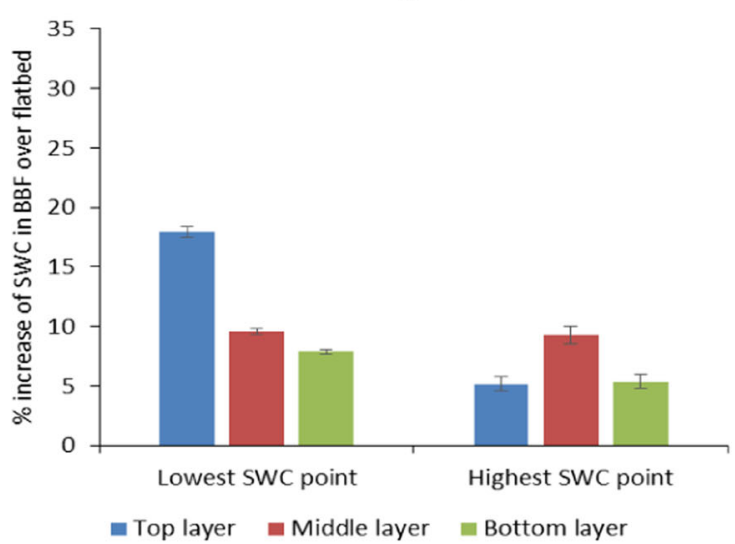

F I G U R E 2 Changes in soil water content (SWC) in broad bed furrows (BBF) over flatbed in the top, middle, and bottom layers in different cropping systems at the lowest and highest water content during 2014-2016. Error bars indicate standard error

Vertisol, such as formation of large cracks in furrows during the dry period before the rainy season and formation of micro-cracks on raised beds during the dry period within the rainy season. This characteristics of Vertisols significantly reduced runoff in BBF and increased SWC compared to the flatbed planting. The lower SWCs in flatbed may be due to high runoff towards the slope, which accounts for a decreased time to infiltrate. Another reason for lower SWC in flatbed could be reduced internal drainage due to compaction of soil, which leads to poor soil water conservation (Hati et al., 2013; Pathak et al., 2011; Patil \& Sheelavantar, 2004; Singh et al., 1999).

BBFs in the present study site were prepared where slope of the land was $0.4-0.8 \%$ and maximum length of the furrow was approximately $120 \mathrm{~m}$. The authors believe that BBF would increase SWC as an efficient LWM practice for larger sized fields with $0.4-0.8 \%$ slope of land and for longer furrows (e.g., 300 or 1,000 m). However, results of SWC in BBF would also depend upon components like intensity of rainfall and dry period before the rainy event.
Results of BBFs in the present study could be recommended not only in India, where average size of land holdings is 0.38 ha (Government of India, 2018), but also in other tropical countries where land holdings are larger and water scarcity is an issue.

It is important to note that SWC in SATs fluctuates abruptly due to erratic behavior of rainfall, that is, rainy event with high rainfall or dry period within rainy season. Thus, SWC reached extreme points (highest in heavy rain and lowest in dry period) during the crop growing period. Such extreme situations in SATs would be an area for research to understand the layer-wise trend of SWC. Furthermore, the percentage increase in SWC at the lowest point has higher significance than highest SWC point for the crops in SAT region. Therefore, in the present study, $\mathrm{BBF}$ and flatbed were evaluated at extreme points, that is, during highest and lowest SWC points as is shown in Figure 2.

A detailed analysis of SWC data revealed that the SWC in BBF was higher over flatbed in lowest and highest SWC points in all the three cropping systems. Layer-wise computation of SWC data across three cropping systems 

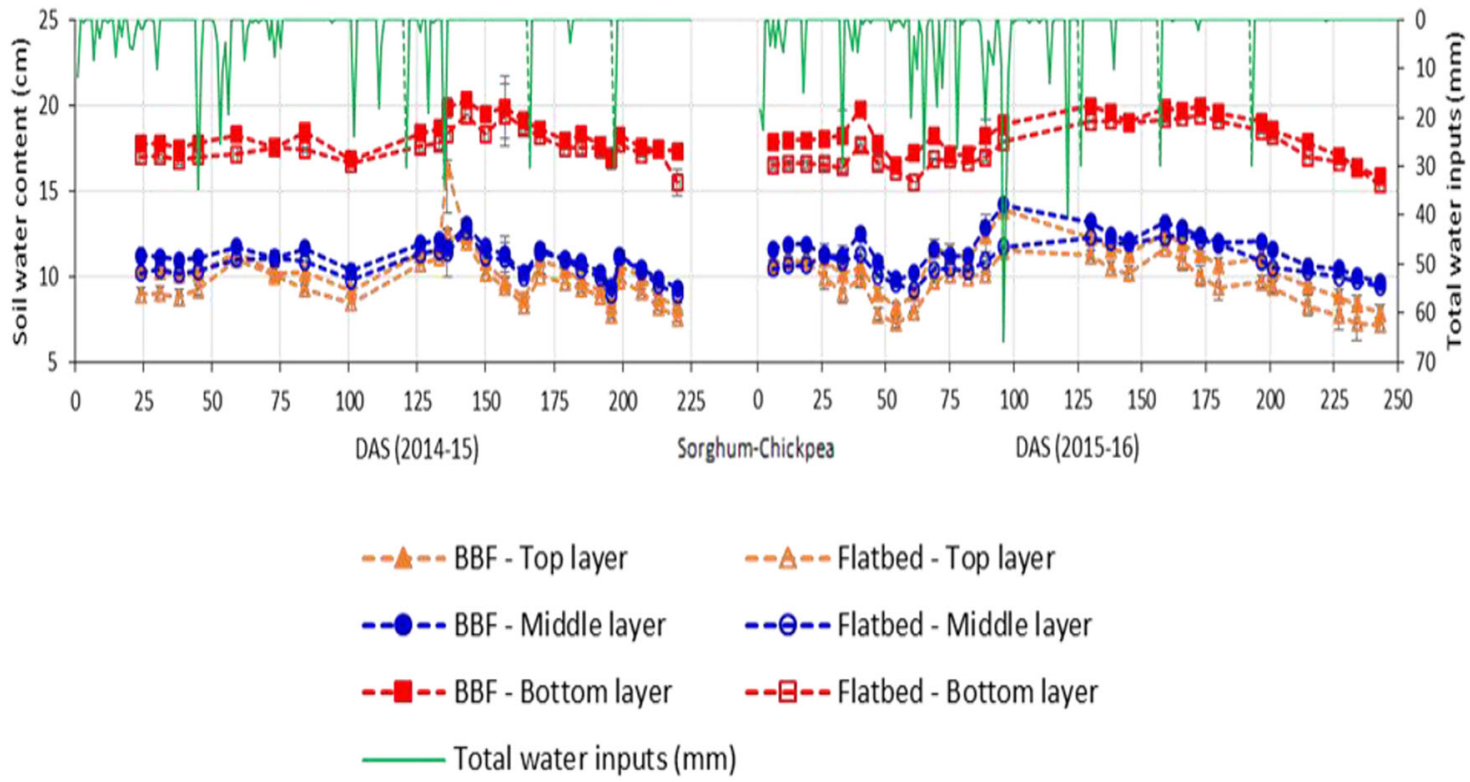

F I G U R E 3 Soil water content (cm) in the top, middle, and bottom soil layers of broad bed furrows (BBF) and flatbed and water inputs in days after sowing (DAS) for sorghum-chickpea cropping system during 2014-2015 and 2015-2016. Error bars indicate standard error

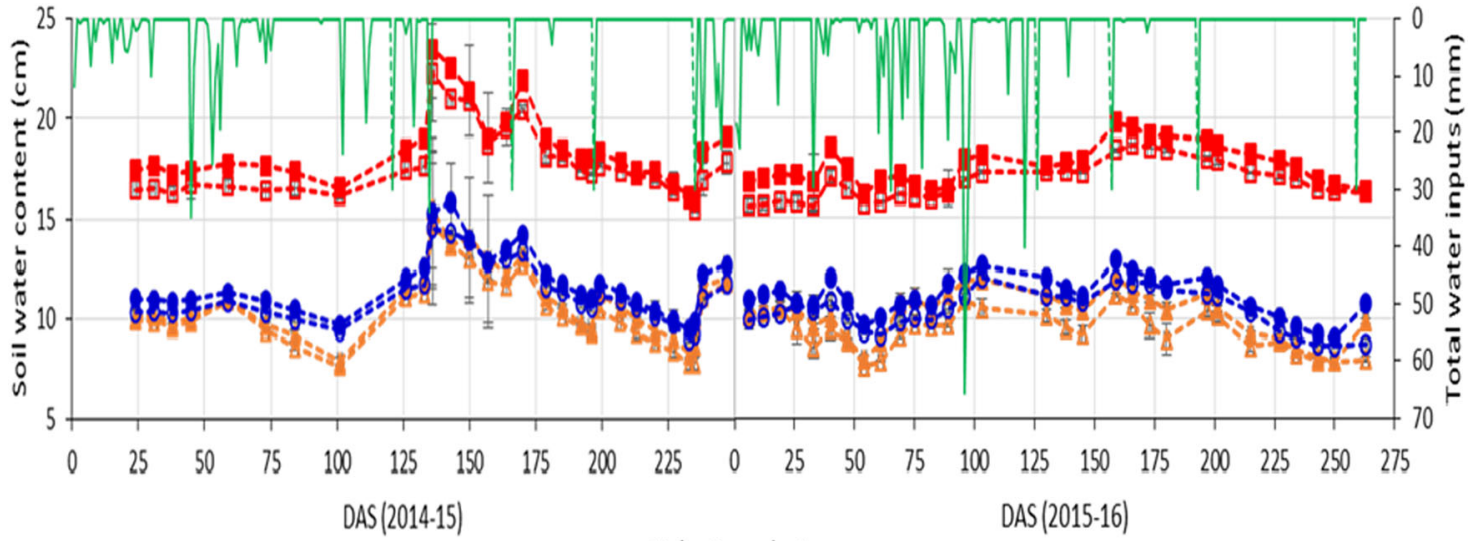

Maize-Groundnut

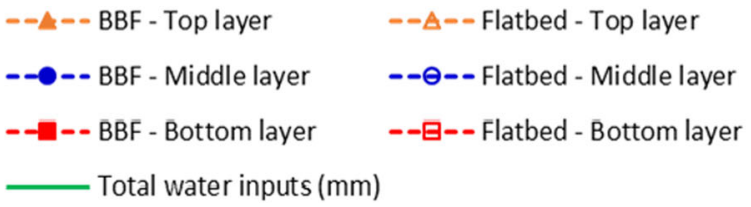

F I G U R E 4 Soil water content (cm) in the top, middle, and bottom soil layers of broad bed furrows (BBF) and flatbed and water inputs in days after sowing (DAS) for maize-groundnut cropping system during 2014-2015 and 2015-2016. Error bars indicate standard error

(Figure 2) indicated that the percent increase of SWC in BBF over flatbed at the both lowest and highest SWC point showed a decreasing trend as the soil depth increased, that is, bottom $<$ middle $<$ top layer.

The SWC at the lowest point in BBF was $9.97 \%$ higher than flatbed in the top layer, $4.66 \%$ higher in the middle layer, and $2.86 \%$ higher in bottom layer in the sorghum-chickpea cropping system during 2014-2016. Whereas at the highest point, the increase of SWC in BBF was $29.60 \%$ higher than flatbed in the top layer, $11.25 \%$ higher in the middle layer, and $4.41 \%$ higher in the bottom layer. A similar trend of SWC among different layers was noted for the maize-groundnut system but with a lower increase of SWC in BBF over flatbed. Contrary to the above sequential cropping, the pearl millet 


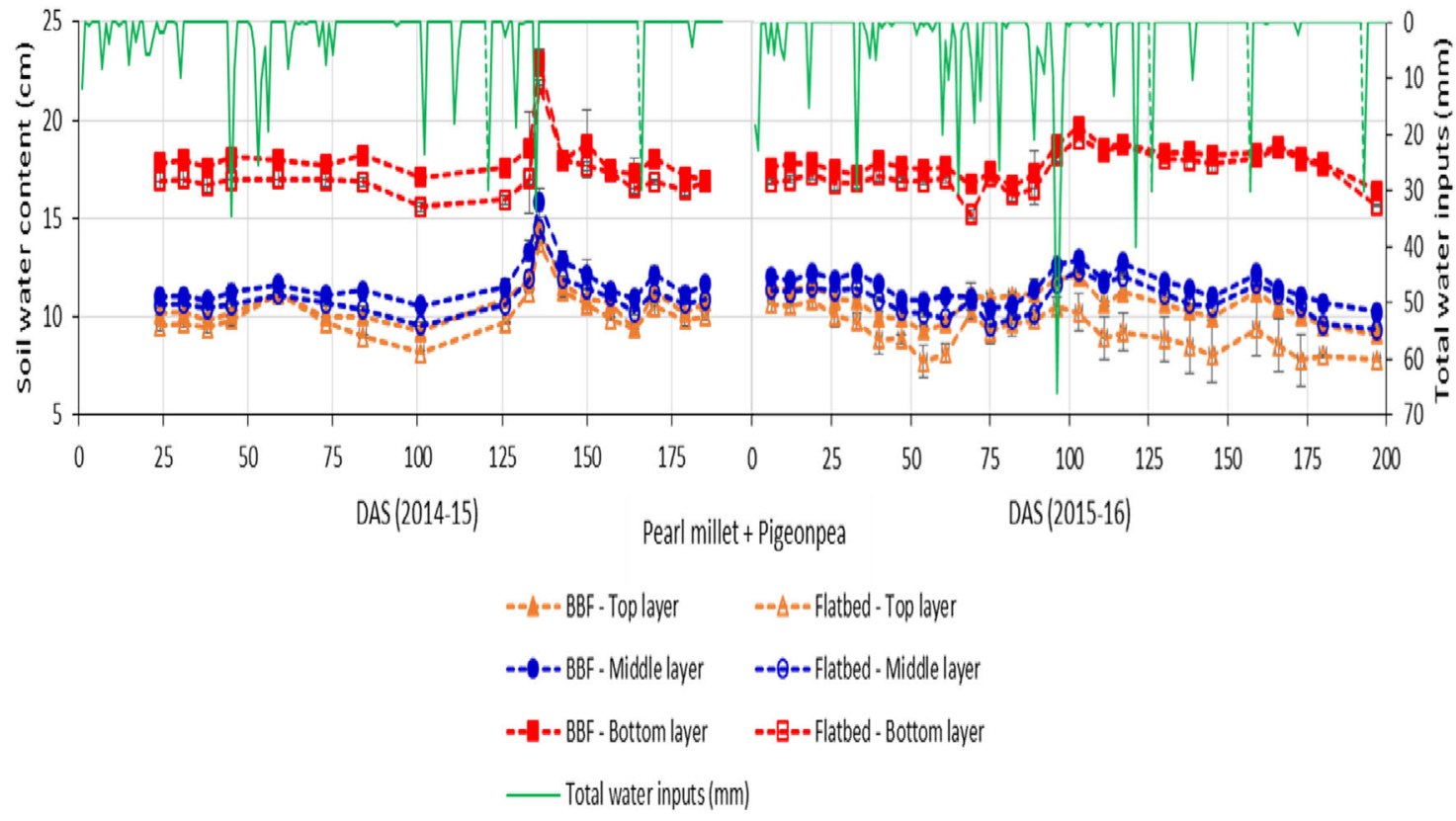

F I G U R E 5 Soil water content (cm) in the top, middle, and bottom soil layers of broad bed furrows (BBF) and flatbed and water inputs in days after sowing (DAS) for pearl millet + pigeonpea cropping system during 2014-2015 and 2015-2016. Error bars indicate standard error

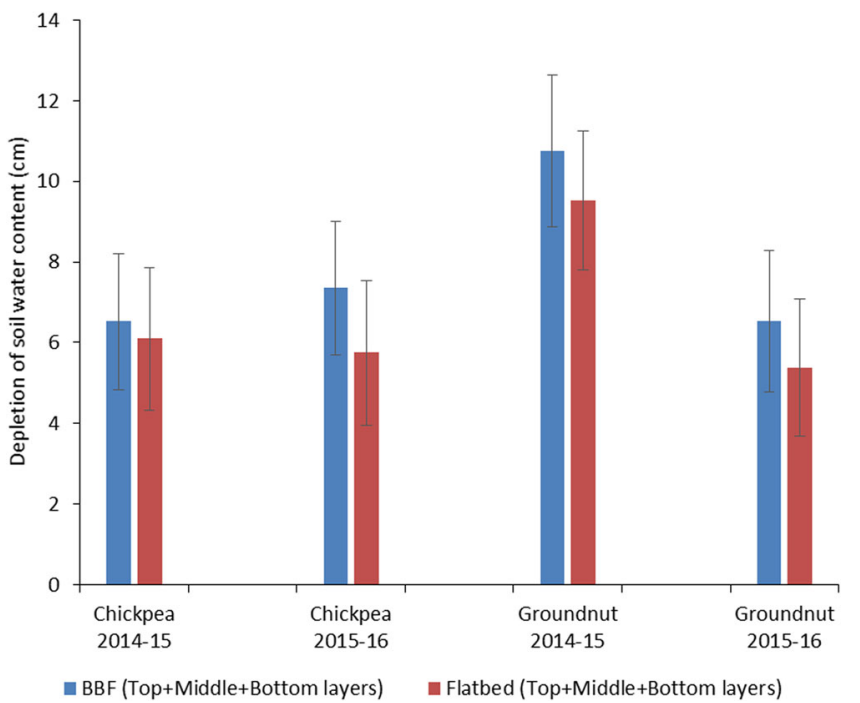

F I G U R E 6 Depletion of soil water content from broad bed furrows (BBF) and flatbed between two successive irrigations in chickpea and groundnut during 2014-2015 to 2015-2016. Error bars indicate standard error

+ pigeonpea intercropping showed a higher increase in the SWC in BBF over flatbed at lowest SWC point than at the highest SWC point.

The increase of SWC in BBF over flatbed at lowest and highest water content point showed a decreasing trend with increasing soil depth in the three cropping systems. This could be due to poor internal drainage of Vertisols which resulted in less water infiltration through deep drainage from top to bottom soil layer. This implies that poor SWC and groundwater recharging occurred in middle and bottom layers of soil. Moreover, infiltration behavior in Vertisols is influenced by the formation of micro-cracks during the dry period within the rainy season. These micro-cracks may have contributed to infiltration and recharging soil water up to the top layer compared to the middle and bottom layers of soil. These results are in corroboration with a long term study from 1976 to 2010 (Pathak, Sudi, Wani, \& Sahrawat, 2013) on hydrological behavior of Alfisols and Vertisols in the semi-arid zone, wherein low ( $<750-\mathrm{mm}$ annual rainfall) and medium (750- to $900-\mathrm{mm}$ annual rainfall) rainfall regions with Vertisols, the mean annual deep drainage was 3 and 13\% respectively. The same study (Pathak et al., 2013) also reported poor groundwater recharge, that is, poor infiltration, and thereby decreased SWC in middle and bottom layers of soil compared to the top layer of soil.

In the present study at the lowest SWC point, it is important to note that the increase in SWC in BBF over flatbed was higher in the pearl millet + pigeonpea intercrop system than in the sorghum-chickpea and maize-groundnut sequential cropping systems. This might be due to combined effect of leaf fall of pigeonpea, canopy shading, different rooting pattern in the intercropping system, and reduced throughfall of rainwater on the soil surface.

A detailed analysis of SWC data showed that the lowest SWC during 2014-2016 was observed between grain filling stage to physiological maturity, wherein maximum leaf fall 
T A B L E 4 Effect of cropping systems, land water, and nutrient management practices on systems equivalent yield during 2014-2015 and 2015-2016. SEM, standard error of the mean; LSD, least significant difference; NS, not significant

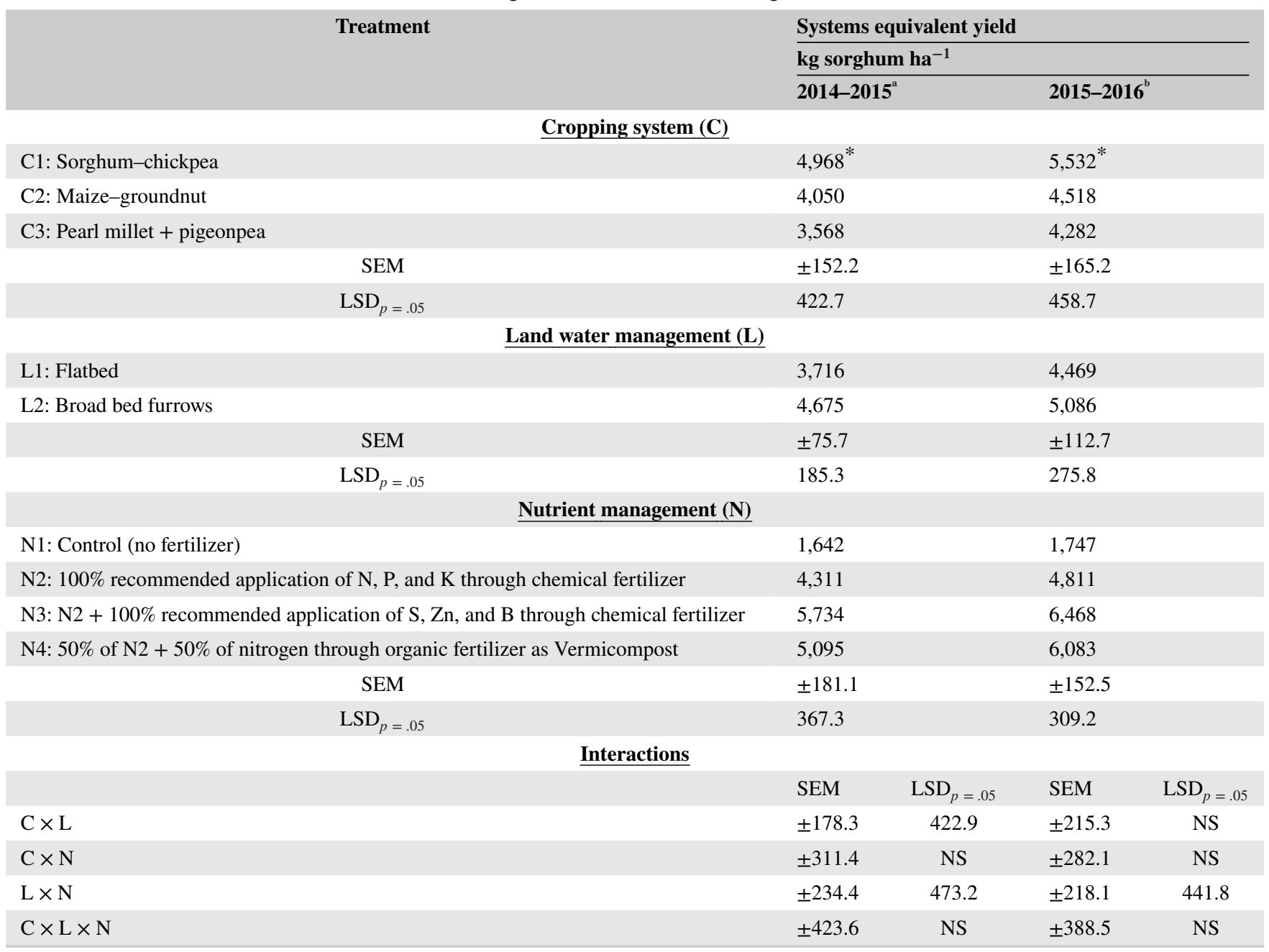

*Significant at the .05 probability level.

${ }^{a}$ Market prices in 2014-2015: 15.30 Indian Rupees (INR) per kg sorghum, 13.10 INR per kg maize, 12.50 INR per kg pearl millet, 43.50 INR per kg pigeonpea, 31.75 INR per kg chickpea, and 40.00 INR per kg groundnut.

${ }^{\mathrm{b}}$ Market prices in 2015-2016: 15.70 INR per kg sorghum, 13.25 INR per kg maize, 12.75 INR per kg pearl millet, 46.25 INR per kg pigeonpea, 35.00 INR per kg chickpea, and 40.30 INR per kg groundnut.

occurred in pigeonpea below plant periphery and covered the soil surface. Fallen leaves of pigeonpea may have played the role of a barrier, thus allowing little solar radiation to reach the soil surface and reducing soil temperature. This reduced the evaporative loss of water and conserved soil water. In addition, fallen leaf may have added a large amount of organic matter which not only stimulates biological properties but also improves physical properties of soil, which improves water-holding capacity and SWC. Several researchers showed that a large amount of organic matter added through fallen leaves, which continuously add carbon in soil (Garg, Karlberg, Wani, \& Berndes, 2011), improved soil physical properties and improved the water-holding capacity of the soil (Zhu et al., 2010). Wani et al. (2012) also revealed that the water-holding capacity of soil increased by $35 \%$ at $30 \mathrm{kPa}$ and $21 \%$ at $1,500 \mathrm{kPa}$ SWC under the leaf fall of Jatropha and increased water retention (Ogunwole et al., 2008) of soil.

Another study (Hsiao \& Xu, 2005) stated that crop canopy coverage reduced soil temperature due to the smaller reach of solar radiation on the soil surface and resulted in soil water conservation. In addition to shading effect, two crop species in an intercrop, such as legumes and cereals, consisting of different rooting patterns explored a larger total soil volume to fulfill water requirement and utilized water appropriately from different soil depths (Ofori et al., 2014). Furthermore, the shading effect may have also reduced the intensity of rainfall and throughfall, that is, direct falling of raindrops on the soil surface. Thus, rainwater remained on vegetation for a long time and was slowly coalesced through leaf drips 
T A B L E 5 Systems equivalent yield ( $\mathrm{kg}$ sorghum $\left.\mathrm{ha}^{-1}\right)$ as influenced by land water management and nutrient management practices during 2014-2015 and 2015-2016. SEM, standard error of the mean; LSD, least significant difference; NS, not significant

\begin{tabular}{|c|c|c|c|}
\hline \multirow[t]{2}{*}{ Nutrient management practices } & \multicolumn{3}{|c|}{ Land water management practice $(\mathrm{L})$} \\
\hline & L1: Flatbed & L2: Broad bed furrows & Average \\
\hline \multicolumn{4}{|l|}{$\underline{2014-2015}^{\mathrm{a}}$} \\
\hline N1: Control (no fertilizer) & 1,792 & 1,492 & 1,642 \\
\hline $\mathrm{N} 2: 100 \%$ recommended application of $\mathrm{N}, \mathrm{P}$, and $\mathrm{K}$ through chemical fertilizer & 3,778 & 4,843 & 4,310 \\
\hline Average & 3,715 & 4,675 & \\
\hline SEM & \pm 234.4 & & \\
\hline $\mathrm{LSD}_{p}=0.05$ & 473.2 & & \\
\hline \multicolumn{4}{|l|}{$\underline{2015-2016}$} \\
\hline $\mathrm{N} 4: 50 \%$ of $\mathrm{N} 2+50 \%$ of nitrogen through organic fertilizer as Vermicompost & 5,448 & 6,718 & 6,083 \\
\hline Average & 4,469 & 5,086 & \\
\hline SEM & \pm 218.1 & & \\
\hline $\mathrm{LSD}_{p}=.05$ & 441.8 & & \\
\hline
\end{tabular}

${ }^{*}$ Significant at the .05 probability level.

${ }^{a}$ Market prices in 2014-2015: 15.30 Indian Rupees (INR) per kg sorghum, 13.10 INR per kg maize, 12.50 INR per kg pearl millet, 43.50 INR per kg pigeonpea, 31.75 INR per kg chickpea, and 40.00 INR per kg groundnut.

${ }^{\mathrm{b}}$ Market prices in 2015-2016: 15.70 INR per kg sorghum, 13.25 INR per kg maize, 12.75 INR per kg pearl millet, 46.25 INR per kg pigeonpea, 35.00 INR per kg chickpea, and 40.30 INR per kg groundnut.

and stem flow, which increased water infiltration into the soil layers (Ghanbari, Dahmardeh, Siahsar, \& Ramroudi, 2010; Walker \& Ogindo, 2003).

\section{2 | Effect of cropping systems on soil water dynamics}

In the sorghum-chickpea sequential cropping system (20142015; Figure 3), the SWC in BBF varied in the range of 8.27 to $16.25 \mathrm{~cm}$ in the top layer, 9.36 to $13.03 \mathrm{~cm}$ in the middle layer, and 16.83 to $20.30 \mathrm{~cm}$ in the bottom layer. The SWC for corresponding layers in flatbed were lower, that is, 7.63 to $12.54 \mathrm{~cm}$ in the top layer, 8.94 to $12.72 \mathrm{~cm}$ in the middle layer, and 15.2 to $19.44 \mathrm{~cm}$ in the bottom layer. Similar results were recorded in the second year of sorghum-chickpea (2015-2016; Figure 3), where SWC in BBF was higher and varied in the range of 7.87 to $13.84 \mathrm{~cm}$ in the top layer, 9.63 to $14.16 \mathrm{~cm}$ in the middle layer, and 15.82 to $19.97 \mathrm{~cm}$ in the bottom layer.

The SWC in maize-groundnut (sequential cropping; Figure 4) and pearl millet + pigeonpea (intercropping; Figure 5) were also higher in BBF than the flatbed during 2014-2015 and 2015-2016.
The total water inputs in cropping systems (rainfall + irrigation) were 353 and $538 \mathrm{~mm}$ in sorghum-chickpea, 479 and $568 \mathrm{~mm}$ in maize-groundnut, and 370 and $563 \mathrm{~mm}$ in pearl millet + pigeonpea cropping system in 2014-2015 and 2015-2016, respectively. In sorghum-chickpea, average SWC in BBF was higher than flatbed by $0.82 \mathrm{~cm}$ in 2014 2015 and $1.08 \mathrm{~cm}$ in $2015-2016$ in the top layer, by $0.45 \mathrm{~cm}$ in 2014-2015 and $0.78 \mathrm{~cm}$ in 2015-2016 in the middle layer, and by $0.67 \mathrm{~cm}$ in $2014-2015$ and $0.86 \mathrm{~cm}$ in 2015-2016 in the bottom layer. Similarly in maize-groundnut sequential cropping system, yearly average of layer-wise SWC in BBF was higher than flatbed by $0.48 \mathrm{~cm}$ in $2014-2015$ and $0.81 \mathrm{~cm}$ in 2015-2016 in the top layer, by $0.56 \mathrm{~cm}$ in $2014-2015$ and $0.74 \mathrm{~cm}$ in $2015-2016$ in the middle layer, and by $0.79 \mathrm{~cm}$ in 2014-2015 and $0.80 \mathrm{~cm}$ in 2015-2016 in the bottom layer. Likewise in pearl millet + pigeonpea intercropping system, yearly average of layer-wise SWC in BBF was higher than the flatbed by $0.57 \mathrm{~cm}$ in $2014-2015$ and $1.46 \mathrm{~cm}$ in 2015-2016 in the top layer, by $0.74 \mathrm{~cm}$ in $2014-2015$ and $0.68 \mathrm{~cm}$ in 2015-2016 in the middle layer, and by $0.93 \mathrm{~cm}$ in 2014-2015 and $0.52 \mathrm{~cm}$ in 2015-2016 in the bottom layer.

Higher SWC in BBF than the flatbed in all three studied cropping systems reconfirms our notion that raised beds in 
T A B L E 6 Effect of cropping systems, land water management, and nutrient management strategies on water productivity during 2014-2015 and 2015-2016. SEM, standard error of the mean; LSD, least significant difference; NS, not significant

\begin{tabular}{|c|c|c|c|c|}
\hline \multirow[t]{3}{*}{ Treatment } & \multicolumn{4}{|c|}{ Water productivity } \\
\hline & \multicolumn{4}{|c|}{$\mathrm{kg} \mathrm{m}^{-3}$} \\
\hline & \multicolumn{2}{|c|}{$2014-2015$} & \multicolumn{2}{|c|}{ 2015-2016 } \\
\hline C1: Sorghum-chickpea & \multicolumn{2}{|l|}{$1.40^{*}$} & \multicolumn{2}{|l|}{$1.02^{*}$} \\
\hline C2: Maize-groundnut & \multicolumn{2}{|l|}{0.89} & \multicolumn{2}{|l|}{0.79} \\
\hline $\mathrm{LSD}_{p}=0.05$ & \multicolumn{2}{|l|}{.09} & \multicolumn{2}{|l|}{.08} \\
\hline \multicolumn{5}{|l|}{ Land water management $(\mathrm{L})$} \\
\hline L1: Flatbed & \multicolumn{2}{|l|}{0.86} & \multicolumn{2}{|l|}{0.73} \\
\hline L2: Broad bed furrows & \multicolumn{2}{|l|}{1.08} & \multicolumn{2}{|l|}{0.82} \\
\hline N1: Control (no fertilizer) & \multicolumn{2}{|l|}{0.38} & \multicolumn{2}{|l|}{0.28} \\
\hline N2: $100 \%$ recommended application of $\mathrm{N}, \mathrm{P}$, and $\mathrm{K}$ through chemical fertilizer & \multicolumn{2}{|l|}{0.99} & \multicolumn{2}{|l|}{0.78} \\
\hline $\mathrm{N} 3: \mathrm{N} 2+100 \%$ recommended application of $\mathrm{S}, \mathrm{Zn}$, and B through chemical fertilizer & \multicolumn{2}{|l|}{1.33} & \multicolumn{2}{|l|}{1.05} \\
\hline $\mathrm{N} 4: 50 \%$ of $\mathrm{N} 2+50 \%$ of nitrogen through organic fertilizer as Vermicompost & \multicolumn{2}{|l|}{1.18} & 0.98 & \\
\hline SEM & \pm .03 & & \pm .02 & \\
\hline $\mathrm{LSD}_{p}=.05$ & .07 & & .05 & \\
\hline$\underline{\text { Interactions }}$ & & & & \\
\hline & SEM & $\mathrm{LSD}_{p}=.05$ & SEM & $\mathrm{LSD}_{p}=.05$ \\
\hline $\mathrm{C} \times \mathrm{L}$ & \pm .04 & .097 & \pm .036 & NS \\
\hline
\end{tabular}

*Significant at the .05 probability level.

BBF decreased runoff, which allowed more time for water to infiltrate into deeper layers. Furthermore, the increased surface area due to raised beds augmented horizontal movement of water from furrow to the inner layer of BBF better than the flatbed.

\section{3 | Depletion of SWC between two successive irrigations}

Higher SWC in BBF than the flatbed and resilience of BBF over flatbed at lowest and highest SWC points showed the advantage of BBF over flatbed. In the rainy season, depletion of SWC fluctuates intermittently due to erratic rainfall and could not be analyzed appropriately. Therefore, for precise evaluation of the depletion of SWC in BBF and flatbed, the period between two successive irrigations (170-196 DAS in 2014-2015 and 197-234 DAS in 2015-2016) in post-rainy season was considered in the present study. Figure 6 indicated that the depletion of SWC (top + middle + bottom layers) between two successive irrigations in BBF were higher than the flatbed.

The sampling period fell during the grain filling and pod development stages, the latter of which is one of the critical growth stages of chickpea and groundnut, where the demand for water is high and plants remove more water with its availability. Moreover, between two successive irrigations, that is, in the post-rainy season (dry period), plants are likely to shift to stress condition and extracted more water from deeper layers of soil profile due to high water availability in BBF. In addition, surrounding environmental conditions forced plants to draw more water, which is essential for evapotranspiration and to maintain photosynthetic activities under reduced water availability. Thus, increased evapotranspiration in critical crop growth stages and under environmental stress like no rainfall contributed to higher depletion of SWC in BBF than the flatbed. 
T A B L E 7 Water productivity $\left(\mathrm{kg} \mathrm{m}^{-3}\right)$ as influenced by cropping systems and nutrient management practices during 2014-2015 and 2015-2016. SEM, standard error of the mean; LSD, least significant difference; NS, not significant

\begin{tabular}{|c|c|c|c|c|}
\hline \multirow[t]{2}{*}{ Nutrient management practices } & \multicolumn{4}{|c|}{ Cropping systems } \\
\hline & $\begin{array}{l}\text { C1: Sorghum- } \\
\text { chickpea }\end{array}$ & $\begin{array}{l}\text { C2: Maize- } \\
\text { groundnut }\end{array}$ & $\begin{array}{l}\text { C3: Pearl millet } \\
\text { + pigeonpea }\end{array}$ & Average \\
\hline N1: Control (no fertilizer) & 0.608 & 0.331 & 0.222 & 0.387 \\
\hline $\begin{array}{l}\mathrm{N} 2: 100 \% \text { recommended application of } \mathrm{N} \text {, } \\
\mathrm{P} \text {, and } \mathrm{K} \text { through chemical fertilizer }\end{array}$ & 1.404 & 0.912 & 0.668 & 0.995 \\
\hline $\begin{array}{l}\mathrm{N} 4: 50 \% \text { of } \mathrm{N} 2+50 \% \text { of nitrogen through } \\
\text { organic fertilizer as Vermicompost }\end{array}$ & 1.68 & 1.114 & 0.747 & 1.18 \\
\hline Average & 1.407 & .89 & .623 & \\
\hline N1: Control (no fertilizer) & 0.444 & 0.24 & 0.179 & 0.288 \\
\hline $\begin{array}{l}\mathrm{N} 2: 100 \% \text { recommended application of } \mathrm{N} \text {, } \\
\mathrm{P} \text {, and } \mathrm{K} \text { through chemical fertilizer }\end{array}$ & 1.054 & 0.806 & 0.506 & 0.789 \\
\hline $\begin{array}{l}\mathrm{N} 3: \mathrm{N} 2+100 \% \text { recommended application } \\
\text { of } \mathrm{S}, \mathrm{Zn} \text {, and B through chemical } \\
\text { fertilizer }\end{array}$ & $1.338^{*}$ & 1.144 & 0.69 & 1.057 \\
\hline $\begin{array}{l}\mathrm{N} 4: 50 \% \text { of } \mathrm{N} 2+50 \% \text { of nitrogen through } \\
\text { organic fertilizer as Vermicompost }\end{array}$ & 1.278 & 0.988 & 0.696 & 0.987 \\
\hline Average & 1.029 & .795 & .518 & \\
\hline
\end{tabular}

"Significant at the .05 probability level.

\subsection{System equivalent yield}

Effect of cropping system with nutrient and LWM on SEY is presented in Table 4. Significantly higher SEY were recorded in sorghum-chickpea $\left(4,968 \mathrm{~kg}\right.$ sorghum ha ${ }^{-1}$ in 2014-2015 and $5,532 \mathrm{~kg}$ sorghum ha ${ }^{-1}$ in 2015-2016), followed by maize-groundnut $\left(4,050 \mathrm{~kg}\right.$ sorghum $\mathrm{ha}^{-1}$ in 2014-2015 and 4,518 kg sorghum ha ${ }^{-1}$ in 2015-2016), and pearl millet + pigeonpea $\left(3,568 \mathrm{~kg}\right.$ sorghum $\mathrm{ha}^{-1}$ in $2014-2015$ and $4,282 \mathrm{~kg}$ sorghum ha- ${ }^{-1}$ in 2015-2016). The SEY of maizegroundnut and pearl millet + pigeonpea were comparable, but they were significantly lower than sorghum-chickpea system in 2015-2016.

Between the two LWM practices, higher SEY $(4,675 \mathrm{~kg}$ sorghum ha ${ }^{-1}$ in 2014-2015 and 5,086 kg sorghum ha ${ }^{-1}$ in 2015-16) was recorded in BBF than the flatbed $(3,716 \mathrm{~kg}$ sorghum ha ${ }^{-1}$ in 2014-2015 and 4,469 kg sorghum ha ${ }^{-1}$ in 2015-2016).

Among the four nutrient management practices, significantly higher SEY (5,734 kg sorghum ha ${ }^{-1}$ in 2014-2015 and 6,468 kg sorghum ha ${ }^{-1}$ in 2015-2016) were recorded in N3. The higher SEY of N3 was followed by the N4 treatment during both the years of study. The N2 treatment gave significantly lower SEY than the rest of the nutrient management practices.

The data presented in Table 5 indicated that treatment L2N3 had the highest significant SEY $(6,736 \mathrm{~kg}$ sorghum $\mathrm{ha}^{-1}$ in 2014-2015 and 7,211 kg sorghum ha- in 20152016). The lowest system equivalent yield was recorded in L1N1. The flatbed with N3 and N4 were at par with each other during 2014-2015 and 2015-2016.

Application of recommended dose of macronutrients to crops may have influenced physiological processes like proteins formation, energy storage and transfer, controlled transpiration and water uptake through regulated stomatal openings, activity of rhizobia, and formation of root nodules which fixate more atmospheric $\mathrm{N}$. Moreover, micronutrients like $\mathrm{Zn}$ helped enzyme activation and electron transport, whereas B is necessary for proper pollination and formation of fruit or seed setting. Thus, combined application of macroand micronutrients in N3 likely contributed to enhanced photosynthetic process and appropriate transportation of food 
T A B L E 8 Water productivity $\left(\mathrm{kg} \mathrm{m}^{-3}\right)$ as influenced by land water management and nutrient management practices during 2014-2015 and 2015-2016. SEM, standard error of the mean; LSD, least significant difference; NS, not significant

\begin{tabular}{|c|c|c|c|}
\hline \multicolumn{4}{|l|}{ Water productivity } \\
\hline \multicolumn{4}{|l|}{$\mathbf{k g ~ m}^{-3}$} \\
\hline Nutrient management practices & \multicolumn{3}{|c|}{ Land water management practice } \\
\hline \multicolumn{4}{|l|}{$\underline{2014-2015}$} \\
\hline N1: Control (no fertilizer) & 0.420 & 0.354 & 0.387 \\
\hline $\mathrm{N} 4: 50 \%$ of $\mathrm{N} 2+50 \%$ of nitrogen through organic fertilizer as Vermicompost & 1.063 & 1.298 & 1.180 \\
\hline Average & .864 & 1.083 & \\
\hline SEM & \pm .047 & & \\
\hline $\operatorname{LSD}_{p}=.05$ & .095 & & \\
\hline $\mathrm{N} 3: \mathrm{N} 2+100 \%$ recommended application of $\mathrm{S}, \mathrm{Zn}$, and B through chemical fertilizer & 0.939 & $1.175^{*}$ & 1.057 \\
\hline N4: $50 \%$ of $\mathrm{N} 2+50 \%$ of nitrogen through organic fertilizer as Vermicompost & 0.884 & 1.091 & 0.987 \\
\hline Average & .732 & .828 & \\
\hline SEM & \pm .037 & & \\
\hline $\operatorname{LSD}_{p}=.05$ & .075 & & \\
\hline
\end{tabular}

*Significant at the .05 probability level.

material in plants, which was ultimately reflected in grain yield and SEY. Moreover, higher SEY in BBF could be due to better availability of water, which also transported nutrients throughout the growing period of crops. This enhanced efficient utilization of water and nutrients increased SEY in BBF. Calmak, Kurtz, and Marschner (1995) revealed that application of a recommended dose of macro- and micronutrients may have contributed to the effective functioning of plant's physiological process like maintaining membrane integrity, which enhanced transport of available nutrients. This resulted in better growth and development of crop and thereby higher crop yield than other nutrient treatments. Also, application of micronutrients ( $\mathrm{Zn}$ and B) in 2014-2015 showed yield benefits during the succeeding year (2015-2016) which could be through residual effects of S, Zn, and B (Chander et al., 2013).

\section{5 | Water productivity}

The objective of the present study was to develop an efficient cropping system with higher WP. In this study, each cropping system included two crops (two sequential and one intercropping) which were grown in rainy and post-rainy season, where duration, type, and water requirement of crops were different. Therefore, it would not be appropriate to calculate and compare season WP of each crop. Thus, the WP of each cropping system was calculated at the end of each year.
Among the three cropping systems, significantly higher WP were recorded in sorghum-chickpea $(1.40$ and $1.02 \mathrm{~kg}$ $\left.\mathrm{m}^{-3}\right)$ followed by maize-groundnut $\left(0.89\right.$ and $\left.0.79 \mathrm{~kg} \mathrm{~m}^{-3}\right)$ and pearl millet + pigeonpea $\left(0.62\right.$ and $\left.0.51 \mathrm{~kg} \mathrm{~m}^{-3}\right)$ during 2014-2015 and 2015-2016 respectively (Table 6).

In LWM practices, higher values of WP were recorded in BBF $\left(1.08 \mathrm{~kg} \mathrm{~m}^{-3}\right)$ than the flatbed $\left(0.86 \mathrm{~kg} \mathrm{~m}^{-3}\right)$ during 2014-2015, and corresponding BBF and flatbed values were $0.82 \mathrm{~kg} \mathrm{~m}^{-3}$ and $0.73 \mathrm{~kg} \mathrm{~m}^{-3}$, respectively, in 2015-2016.

Out of four nutrient management practices, the highest significant WP of $1.33 \mathrm{~kg} \mathrm{~m}^{-3}$ (2014-2015) and $1.05 \mathrm{~kg} \mathrm{~m}^{-3}$ (2015-2016) were recorded in the N3 treatment.

The WP depends on SEY and a higher SEY in the sorghum-chickpea cropping system resulted in higher WP than the maize-groundnut and pearl millet + pigeonpea cropping systems. Higher WP in BBF and N3 treatments could be due to the combined effect of higher SWC and the 100\% recommended application of $\mathrm{N}, \mathrm{P}, \mathrm{K}, \mathrm{S}, \mathrm{Zn}$, and $\mathrm{B}$ which enhanced grain production. This combined effect of nutrient and LWM provided a sufficient amount of water and nutrients, which not only increased aboveground crop biomass but also root biomass which effectively utilized water and nutrients. The growth of aboveground crop biomass contributed to efficient conversion of unproductive evaporation loss in productive transpiration, which resulted in increased crop yield and WP. 
During both the years of study (Table 7), cropping systems and nutrient management practices significantly influenced WP, where sorghum-chickpea recorded higher water productivity $\left(1.936 \mathrm{~kg} \mathrm{~m}^{-3}\right.$ in $2014-2015$ and $1.338 \mathrm{~kg} \mathrm{~m}^{-3}$ in 2015-2016) in the N3 treatment. However, in the sorghumchickpea cropping system, N3 was followed by N4 treatment, where WP was $1.680 \mathrm{~kg} \mathrm{~m}^{-3}$ in 2014-2015 and $1.278 \mathrm{~kg}$ $\mathrm{m}^{-3}$ in 2015-2016. Lower WP was recorded in pearl millet + pigeonpea cropping system $\left(0.222 \mathrm{~kg} \mathrm{~m}^{-3}\right.$ in $2014-2015$ and $0.179 \mathrm{~kg} \mathrm{~m}^{-3}$ in 2015-2016) under the $\mathrm{N} 1$ treatment.

During both the years of study, the LWM $\times$ nutrient management was significant (Table 8). Treatment L2N3 recorded higher WP $\left(1.568 \mathrm{~kg} \mathrm{~m}^{-3}\right.$ in 2014-2015 and $1.175 \mathrm{~kg} \mathrm{~m}^{-3}$ in 2015-2016) than the rest of treatment combinations.

\section{4 | CONCLUSIONS}

In SATs, Vertisols and its associated soils have lower WP and system productivity due to reduced soil water content during critical crop growth stages and rainfall variability which included longer dry period and/or heavy rain event. These reasons also compel farmers to retain Vertisols fallow during the rainy and post-rainy season. This study in Vertisols of SATs evaluated BBF and flatbed management practices in sequential and intercropping systems for increased SWC, WP, and systems productivity. Results of the study revealed that the SWC among three cropping systems in BBF was higher than flatbed by $9.35-10.44 \%$ in 0 - to $0.3-\mathrm{m}, 4.56-9.30 \%$ in 0.3 - to $0.6-\mathrm{m}$, and $3.85-5.26 \%$ in $0.6-$ to $1.05-\mathrm{m}$ soil depth. The BBF conserved more soil water than flatbed at lowest and highest SWC. Increased SWC in BBF was mainly due to raised beds which decreased runoff and increased infiltration rate and horizontal movement of rainwater from furrow to the inner layer of broad bed furrows.

When calculating increased SWC in BBF on a hectare basis, the BBF could conserve several thousand liters of soil water, which would support large acreage crop production in SATs. The study also indicated that the sorghum-chickpea sequential cropping system had the highest SEY and WP followed by the maize-groundnut intercropping system and pearl millet + pigeonpea intercropping system when micronutrients were supplemented with the normal fertilizer dose. Therefore, integrated approach of land-water-cropnutrient management practices is relevant in developing resilient dryland systems, and practicing BBF could be an adaptation strategy to rainfall variability and reducing fallow land in SATs for minimizing the effects of future climate change on agricultural production.

\section{ACKNOWLEDGEMENTS}

We acknowledge the support of Dr. A.V.R Kesava Rao, Honorary Fellow, ICRISAT and Dr. Mukund D. Patil, Senior
Scientist, ICRISAT for extending laboratory facilities for soil moisture monitoring and soil physical analysis. The financial support from ICRISAT for execution of the experiment is gratefully acknowledged.

\section{ORCID}

Dillip Kumar Swain

https://orcid.org/0000-0001-9883-3307

\section{R E F E R E N C ES}

Alexandratos, N., \& Bruinsma, J. (2012). World Agriculture towards 2030/2050: The 2012 revision (ESA Working Paper No. 12-03). Rome, Italy: Food and Agriculture Organization.

Barai, V. N., Patil, P. P., \& Patil, B. M. (1991). Effect of conservation practices on soil moisture and crop yield. Indian Journal of Soil Conservation, 19(3), 71-73.

Black, C. A. (Ed.) (1965). Methods of Analysis. Part II: Chemical and Microbial Properties (9th ed., pp. 770-779). Madison, WI: ASACSSA-SSSA.

Boomiraj, K., Wani, S. P., Garg, K. K., Aggarwal, P. K., \& Palanisami, K. (2010). Climate change adaptation strategies for agro-ecosystem-a review. Journal of Agrometeorology, 12(2), 145-160.

Calmak, I., Kurtz, H., \& Marschner, H. (1995). Short term effects of boron, germanium and high light intensity on membrane permeability in boron deficient leaves of sunflower. Physiologia Plantarum, 95(1), 11-18. https://doi.org/10.1111/j.1399-3054.1995.tb00 801.x

Chander, G., Wani, S. P., Sahrawat, K. L., Kamdi, P. J., Pal, C. K., Pal, D. K., \& Mathur, T. P. (2013). Balanced and integrated nutrient management for enhanced and economic food production: Case study from rainfed semi-arid tropics in India. Archives of Agronomy and Soil Science, 59(12), 1643-1658. https://doi.org/10.1080/03650340. 2012.761336

Dudal, R., \& Eswaran, H. (1988). Distribution, properties and classification of Vertisols. In L. P. Wilding \& R. Puentes (eds.), Vertisols: Their distribution, properties, classification and management (pp. 1-22). Washington, DC: Publication Soil Management Support Services, United States Department of Agriculture, Natural Resources Conservation Service.

El-Swaify, S. A., Pathak, P., Rego, T. J., \& Singh, S. (1985). Soil management for optimized productivity under rainfed conditions in the semiarid tropics. In B.A. Stewart (eds.), Advances in soil science (Vol. 1, pp. 1-64). New York, NY: Springer. https://doi.org/10.1007/978-14612-5046-3_1

FAO. (2005). FAOSTAT. Food and agricultural organization. http:// faostat.fao.org/faostat.

Falkenmark, M. (1995). Land and water linkages: A synopsis (FAO Land and Water Bulletin No. 1). Rome, Italy: Food and Agriculture Organization of the United Nations.

Falkenmark, M., \& Rockström, J. (2008). Building resilience to drought in desertification-prone savannas in Sub-Saharan Africa: The water perspective. Natural Resources Forum, 32, 93-102. https://doi.org/ 10.1111/j.1477-8947.2008.00177.x

Garg, K. K., Karlberg, L., Wani, S. P., \& Berndes, G. (2011). Jatropha production on wastelands in India: Opportunities and tradeoffs for soil and water management at the watershed scale. Biofuels, Bioproducts and Biorefining, 5(4), 410-430. https://doi.org/10.1002/ bbb. 312 
Ghanbari, A., Dahmardeh, M., Siahsar, B. A., \& Ramroudi, M. (2010). Effect of maize (Zea mays L.)-cowpea (Vigna unguiculata L.) intercropping on light distribution, soil temperature and soil moisture in arid environment. Journal of Food, Agriculture and Environment, $8(1), 102-108$.

Government of India. (2018). Agricultural Statistics at a glance 2018. Delhi, India: Government of India Controller of Publications.

Greene-Kelly, R. (1974). Shrinkage of clay soils-A statistical correlation with other soil properties. Geoderma, 11(4), 243-257. https:// doi.org/10.1016/0016-7061(74)90052-4

Hati, K. M., Chaudhary, R. S., Mandal, K. G., Misra, A. K., Singh, R. K., Wani, S. P., ... Pathak, P. (2013). Effect of land management and cropping systems on runoff, soil loss, soil water dynamics and crop yield in a Vertisol of Central India. Journal of the Indian Society of Soil Science, 61(2), 79-88.

Helmke, P. A., \& Sparks, D. L. (1996). Lithium, sodium, potassium, rubidium, and cesium. In Methods of Soil Analysis, Part 3: Chemical Methods (pp. 551-574). Madison (WI): ASA-CSSA-SSSA.

Hsiao, T., \& Xu, L. (2005). Evapotranspiration and relative contribution by the soil and the plant. In J. Andrew (Ed.), California Water Plan Update 2005 (Vol. 4, pp. 129-160). Sacramento, CA: California Department of Water Resources.

Ireland, C. R. (2010). Experimental statistics for agriculture and horticulture. Wallingford, UK: CABI.

Keren, R. (1996). Boron. In D. L. Sparks (Ed.), Methods of soil analysis, Part 3: Chemical Methods (pp. 603-626). Madison, WI: ASA-CSSASSSA.

Kesava, R. A. V. R., Wani, S. P., Singh, K. K., Ahmed, M. I., Srinivas, K., Bairagi, S. D., \& Ramadevi, O. (2013). Increased arid and semiarid areas in India with associated shifts during 1971-2004. Journal of Agrometeorology, 15(1), 11-18.

Klute, A. (1986). Methods of Soil Analysis, Part 1: Physical and Mineralogical Methods. Soil Science Society Book Series Vol. 5. Madison, WI: ASA-CSSA-SSSA.

Lindsay, W. L., \& Norvell, W. A. (1978). Development of a DTPA soil test for zinc, iron, manganese, and copper 1. Soil Science Society of America Journal, 42(3), 421-428. https://doi.org/10.2136/sssaj1978. 03615995004200030009x

Michaels, G. H. (1982). The determinants of kharif fallowing on the Vertisol in semi-arid tropical India (Doctoral diss.). University of Minnesota. Retrieved from http://vdsa.icrisat.ac.in/Include/theses/ Thesis26.pdf

Murthy, A. S. P. (1988). Distribution, properties, and management of Vertisols of India. In Advances in Soil Science (pp. 151214). New York, NY: Springer. https://doi.org/10.1007/978-1-46138771-8_4

Nelson, D. W., \& Sommers, L. E. (1996). Total carbon, organic carbon and organic matter. In D. L. Sparks, A. L. Page, P. A. Helmke, \& R. H. Loeppert (Eds.), Methods of Soil Analysis, Part 3 Chemical Methods (Vol. 5, pp. 961-1010). Hoboken, NJ: Wiley.

Ofori, E., Oteng-Darko, P., Berchie, J. N., Nimako, F. O., Yeboah, S., \& Danquah, E. O. (2014). Monitoring of soil moisture regime and water use efficiency under maize-cowpea cropping system. International Journal of Current Microbiology and Applied Sciences, 3(10), 837848.

Olsen, S. R., \& Sommers, L. E. (1982). Phosphorus. In A. G. Norman (Ed.), Methods of Soil Analysis, Part 2: Chemical and Microbiological Properties (2nd ed., pp. 403-430). Madison, WI: SSSA, ASA.
Ogunwole, J. O., Chaudhary, D. R., Ghosh, A., Daudu, C. K., Chikara, J., \& Patolia, J. S. (2008). Contribution of Jatropha curcas to soil quality improvement in a degraded Indian entisol. Soil and Plant Science Plant, 58(3), 245-251. https://doi.org/10.1080/09064710701628925

Parry, M. L., Canziani, O. F., Palutikof, J. P., Van der Linden, P., \& Hanson, C. (Eds.). (2007). Climate Change 2007-Impacts, Adaptation and Vulnerability. Contribution of Working Group II to the Fourth Assessment Report of the Intergovernmental Panel on Climate Change. Cambridge, UK: Cambridge University Press.

Pathak, P., Wani, S. P., \& Sudi, R. (2011). Long-term effects of management systems on crop yield and soil physical properties of semi-arid tropics of Vertisols. Agricultural Sciences, 2(4), 435-442. https://doi.org/10.4236/as.2011.24056

Pathak, P., Sudi, R., Wani, S. P., \& Sahrawat, K. L. (2013). Hydrological behavior of Alfisols and Vertisols in the semi-arid zone: Implications for soil and water management. Agricultural Water Management, 118, 12-21. https://doi.org/10.1016/j.agwat.2012.11.012

Patil, S. N., Muzumdar, G. K., \& Pore, D. B. (1991). Effect of moisture conservation measures on growth and yield of sorghum-pigeonpea intercropping in watershed area. Indian Journal of Soil Conservation, 19(1\&2), 6-11.

Patil, S. L., \& Sheelavantar, M. N. (2004). Effect of cultural practices on soil properties, moisture conservation and grain yield of winter sorghum (Sorghum bicolor L. Moench) in semi-arid tropics of India. Agricultural Water Management, 64(1), 49-67. https://doi.org/ 10.1016/S0378-3774\%2803\%2900178-1

Patil, M. D., Wani, S. P., \& Garg, K. K. (2016). Conservation agriculture for improving water productivity in Vertisol of semi-arid tropics. Current Science, 110(9), 1730-1739. https://doi.org/10.18520/ cs/v110/i9/1730- 1739

Ramesh, T., \& Devasenapathy, P. (2007). Natural resources management on sustainable productivity of rainfed pigeonpea (Cajanus cajan L.). Research Journal of Agriculture and Biological Sciences, 3(3), 124128

Rego, T. J., Rao, V. N., Seeling, B., Pardhasaradhi, G., \& Rao, J. V. D. K. (2003). Nutrient balances-a guide to improving sorghum and groundnut-based dryland cropping systems in semi-arid tropical India. Field Crops Research, 81(1), 53-68. https://doi.org/10.1016/ S0378-4290(02)00199-5

Rego, T. J., Wani, S. P., Sahrawat, K. L., \& Pardhasaradhi, G. (2005). Macro-benefits from boron, zinc and sulfur application in Indian SAT: A step for Grey to Green Revolution in agriculture. Journal of SAT Agricultural Research, 2(1), 1-21.

Rego, T. J., Wani, S.P., Sahrawat, K. L. \& Pardhasaradhi, G. (2007). Widespread deficiencies of sulfur, boron, and zinc in Indian semi-arid tropical soils: On-Farm Crop Responses. Journal of Plant Nutrition, 30(10), 1569-1583. https://doi.org/10.1080/01904160701615475

Ringler, C., Zhu, T., Cai, X., Koo, J., \& Wang, D. (2010). Climate change impacts on food security in Sub-Saharan Africa: Insight from comprehensive climate change scenarios (IFPRI Discussion Paper 01042). Washington, DC: International Food Policy Research Institute.

Sahrawat, K. L., Wani, S. P., Rego, T. J., Pardhasaradhi, G., \& Murthy, K. V. S. (2007). Widespread deficiencies of sulphur, boron and zinc in dryland soils of the Indian semi-arid tropics. Current Science, 93(10), $1428-1432$.

Sahrawat, K. L., Wani, S. P., Parthasaradhi, G., \& Murthy, K. V. S. (2010). Diagnosis of secondary and micronutrient deficiencies and their management in rainfed agroecosystems: Case study from Indian 
semi-arid tropics. Communications in Soil Science and Plant Analysis, 41(3), 346-360. https://doi.org/10.1080/00103620903462340

Sahrawat, K. L., Wani, S. P., Rao, A. S., \& Pardhasaradhi, G. (2011). Management of emerging multinutrient deficiencies: A prerequisite for sustainable enhancement of rainfed agricultural productivity. In S. P. Wani, J. Rockstrom, \& L. Sahrawat (Eds.), Integrated watershed management (pp. 281-314). Leiden, the Netherlands: CRC Press.

Sharma, K. L., Grace, J. K., \& Srinivas, K. (2009). Influence of tillage and nutrient sources on yield sustainability and soil quality under sorghum-mung bean system in rainfed semi-arid tropics. Communications in Soil Science and plant Analysis, 40(15-16), 2579-2602. https://doi.org/10.1080/00103620903113299

Singh, P., \& Verma, R. S. (1996). Nitrogen uptake and quality of pearl millet as influenced by moisture conservation practices and $\mathrm{N}$ fertilization. Indian Journal of Soil Conservation, 24(1), 85-89.

Singh, P., Alagarswamy, G., Pathak, P., Wani, S. P., Hoogenboom, G., \& Virmani, S. M. (1999). Soybean-chickpea rotation on Vertic Inceptisols: I. Effect of soil depth and landform on light interception, water balance and crop yields. Field Crops Research, 63(3), 211-224. https://doi.org/10.1016/S0378-4290(99)00037-4

Sreedevi, T. K., Wani, S. P., Rao, A. V. R. Kesava, Singh, P., \& Ahmed, I. (2009). New science tools for managing community watersheds for enhancing impact. Journal of SAT Agriculture Research, 7, 1-19.

Tabatabai, M. A. (1996). Sulphur. In D. L. Sparks (Ed.), Methods of Soil Analysis, Part 3: Chemical Methods (pp. 921-960). Madison, WI: ASA-CSSA-SSSA.

Thakur, N. S., Kushwaha, B. B., \& Sinha, N. K. (2011). Productivity and water use in kharif sorghum (Sorghum bicolor) under different land configuration and mulching. Indian Journal of Agronomy, 56(1), $47-51$

The World Bank. (2020). Water in agriculture. The World Bank. https:// www.worldbank.org/en/topic/water-in-agriculture

Thorne, D. W., \& Peterson, H. B. (1954). Irrigated soils: Their fertility and management (2nd ed.). New York, NY: The Blakiston Co.

Twomlow, S., Love, D., \& Walker, S. (2008). The nexus between integrated natural resources management and integrated water resources management in southern Africa. Physics and Chemistry of the Earth, Parts A/B/C, 33(8-13), 889-898. https://doi.org/10.1016/j.pce.2008. 06.044

Venkateswarlu, B., Ramakrishna, Y. S., Subba Reddy, G., Mayande, V. M., Korwar, G. R., \& Prabhakar, M. (2008). Rainfed farming: A profile of doable technologies (Central Research Institute for Dryland Agriculture Technical Bulletin). Hyderabad, India: Central Research Institute for Dryland Agriculture.

Viala, E. (2007). Water for food, water for life: A Comprehensive Assessment of water Management in Agriculture. Irrigation Drainage Systems, 22. https://doi.org/10.1007/s10795-008-9044-8

Walker, S., \& Ogindo, H. O. (2003). The water budget of rainfed maize and bean intercrop. Physics and Chemistry of the Earth, Parts $A / B / C$, 28(20-27), 919-926. https://doi.org/10.1016/j.pce.2003.08.018
Wani, S. P., Singh, P., \& Pathak, P. (1999). Methods and management of data for watershed research (ICRISAT Technical Manual No. 5). Patancheru, India: International Crops Research Institute for the Semi-Arid Tropics.

Wani, S. P., Dwivedi, R. S., Ramana, K. V., Vadivelu, A., Navalgund, R. R., \& Pande, A. A. (2002). Spatial distribution of rainy season fallows in Madhya Pradesh: Potential for increasing productivity and minimizing land degradation, Global Theme 3: Water, Soil, and Agrobiodiversity Management (ICRISAT Ecosystem Health Report No. 3). Patancheru, India: International Crops Research Institute for the Semi-Arid Tropics.

Wani, S. P., Joshi, P. K., Ramakrishna, Y. S., Sreedevi, T. K., Singh, P., \& Pathak, P. (2008). A new paradigm in watershed management: A must for development of rain-fed areas for inclusive growth. In A. Swarup, S. Bhan, \& J. S. Bali (Eds.), Conservation farming: Enhancing Productivity and Profitability of Rain-fed Areas (pp. 163-178). New Delhi, India: Soil Conservation of Society of India.

Wani, S. P., Chander, G., Sahrawat, K. L., Rao, C. S., Raghvendra, G., Susanna, P., \& Pavani, M. (2012). Carbon sequestration and land rehabilitation through Jatropha curcas (L.) plantation in degraded lands. Agriculture, Ecosystems \& Environment, 161, 112-120. https: //doi.org/10.1016/j.agee.2012.07.028

Wani, S. P., Chander, G., Sahrawat, K. L., \& Pardhasaradhi, G. (2015). Soil-test-based balanced nutrient management for sustainable intensification and food security: Case from Indian semi-arid tropics. Communications in Soil Science and Plant Analysis, 46(1), 20-33. https://doi.org/10.1080/00103624.2014.988087

Wani, S. P., Chander, G., Sahrawat, K. L., Pal, D. K., Pathak, P., Pardhasaradhi, G., \& Kamdi, P. J. (2016). Sustainable use of natural resources for crop intensification and better livelihoods in the rainfed semi-arid tropics of Central India. NJAS-Wageningen Journal of Life Sciences, 78, 13-19. https:// doi.org/10.1016/j.njas.2015.12.002

Zhu, H., Wu, J., Huang, D., Zhu, Q., Liu, S., Su, Y., ... Li, Y. (2010). Improving fertility and productivity of a highly-weathered upland soil in subtropical China by incorporating rice straw. Plant and Soil, 331(1-2), 427-437. https://doi.org/10.1007/s11104-009-0263-z

Zougmore, R., Zida, Z., \& Kambou, N. F. (2003). Role of nutrient amendments in the success of half-moon soil and water conservation practice in semiarid Burkina Faso. Soil and Tillage Research, 71(2), 143-149.

How to cite this article: Kamdi PJ, Swain DK, Wani SP. Efficient land water management practice and cropping system for increasing water and crop productivity in semi-arid tropics. Agronomy Journal. 2020;112:2552-2568. https://doi.org/10.1002/agj2.20207 